\title{
Auto-ethnography of Self-growth Stories for the Individuation of School Counselors (Professional Teacher-counselors and Professional counselors) Who Are Suffering from 'Between' - Based on Insight in Sandplay Therapy and Dream analysis -
}

\begin{tabular}{|c|c|c|c|}
\hline $\operatorname{Jin~Kim}^{*}$ & Hyun Jung Shin ${ }^{* *}$ & Minji Kim ${ }_{* * * * * * * *}^{* * *}$ & Eunkyung Park \\
\hline Minji Son ${ }^{* * * * *}$ & Kyunghee $\mathrm{Oh}^{* * * * * *}$ & Nayoung Lee & Soojin Lee \\
\hline Eunjung Lee $e^{* * * * * * * * *}$ & Sohee Jeon ${ }^{* * * * * * * *}$ & Sohyun Ji" & Mikyung Jang" \\
\hline
\end{tabular}

This article aims to provide auto-ethnography for self-growth and individuation through the experience of applying sandplay therapy to school counseling of 11 professional teacher-counselors and professional school counselors, changes in the counseling effect, and the counselors' own sandplay therapy and dream symbol analysis. The auto-ethnographical research has mainly been about the experiences of one or two researcher(s)-participant(s), but in this study, 11 researchers-participants

\footnotetext{
* 공동주저자: Baegot Elementaty School (9981wls@korea.kr)

** 공동주저자: Segyeong High School (smshin65@korea.kr)

*** Anyang Duk Hyun Elementary School (snowdrop89@korea.kr)

**** Seongbok High School (yamzee@korea.kr)

****** Hyeonhwa High School (mjson887@korea.kr)

****** Anyang Elementary School (okh1221@korea.kr)

******* Goyang Office of Education Wee Center (dj120727@korea.kr)

********* Seoul Youngseo Elementary School (soojinzing@sen.go.kr)

********* Ansong High School (familylove@korea.kr)

********** Oma Middle School(wjsthgml123@korea.kr)

************ Kwangnam Middle School (jiji00@korea.kr)

************ Corresponding Author: Departiment of Child Welfare, Namseouniversity (jangmiky@nsu.ac.kr)
} 
Journal of Symbols \& Sandplay Therapy, Vol.12 No.2.

participated in the study to express and inform their common experiences in school counseling. The researcher-participants have experience of school counseling from 2 years and 5 months to 11 years and 5 months, and they are all female counselors. Research data include dreams and dream associations, sandpictures and association about sandplay pictures, related life events and experiences, contemplation, recollection, insights, observations of researchers/research participants, sharings by group SNS, individual interviews have been used. The four common themes are found: 1. dreaming of becoming school teacher-counselor/school counselor, 2. frustration: self-blame and resentment, 3. searching for breakthrough: finding identity, 4. accepting incompleteness, which is still in progress. Among them, searching for breakthrough: finding identity has two sub-themes: sandplay and dream: encounter with the inner world and wrestling with regrets for children.

Keywords : professional school teacher-counselor, professional school counselor, individuation, self-growth, sandplay therapy, dream symbol analysis, auto-ethnography

\section{I . Introduction}

As school counselors (professional school teacher-counselor, professional school counselor), we are having a hard time trying to alleviate the difficulties of the children we meet at schools. Our efforts towards this goal started from our undergraduate courses. Even after entering the counseling-related department, we invested a lot of time and money while competing for a teaching job or studying at a graduate school. And in order to pass the teacher appointment test that follows, we passed through a process that was difficult enough to be called a 'state examination'. Some have also spent many years trying to acquire counseling related qualifications to become professional school counselors. Through this hard and difficult process, we became 'professional school teacher-counselors' and 'professional school counselors'. That is why we became a 'counselor' armed with a sense of duty and pride to help students grow in the school field.

As time passed, however, we found ourselves struggling with many things 'in-between' various things. We got caught up in questions such as 'Am I a teacher or a counselor?', 'Are the 
students I meet clients or students', and 'Am I providing sincere counseling?'. Staying alone in a special room (counseling room), we meet children who often visit the counseling room complaining of various psychological and emotional difficulties, and sometimes we encounter other students who want to take care of them like mother, all day long. As this situation repeated, it was not easy for us to structure the counseling session we learned from counseling studies, and we thought about what the problem was, and blamed ourselves for our lack of professionalism as counselors.

We are often confused between the needs of visiting students, the needs of our fellow teachers, and the role of the counselor. Sending students who were hard to handle in the classroom to the counseling room, homeroom teachers and subject teachers revealed their expectations that we would solve the students' problems like magic, which created pressure in that we are required to meet the different and sometimes conflicting expectations of members in school. In addition, it is very difficult to consult the students without the active help of the student's family, and we felt sorry for the 'student' who we took in, without collecting a wealth of information. Even in part, we still blamed ourselves for whether or not it was due to our lack of ability as "counselors".

We also had to struggle with the relationship between the subject teacher and the school administrator (principal, vice principal). We, who regard confidentiality of counseling as the core of vocational ethics, are restricted from sharing counseling contents with the client. Moreover, one professional school teacher-counselor or professional school counselor assigned to each school should plan and operate counseling services for all students. As a result, as one counselor with the only unique job of counseling in the school, we sometimes felt alienated, as if we were alone, and suffered a lack of belonging as a marginal employee. Thinking that this confusion is also caused by a lack of professionalism as a counselor, we believed that this could be resolved by improving our professionalism as a counselor, by training at a counseling-related society, joining a research group, or going on to graduate school.

In the process of trying to become a sincere professional school teacher-counselor or professional school counselor, we had to suffer from the worry and regret of "what about my family?'. Just as we strive to be a competent professional school teacher-counselor or professional school counselor at the schools, we thought we should do our best for our family and home. When we could not balance both, we blamed ourselves and could not help but feel guilty. 
Journal of Symbols \& Sandplay Therapy, Vol.12 No.2.

So we started the process of getting to know ourselves and life. We felt there was an inner 'pressure' that had no choice but to begin within us. Otherwise, we felt a 'fear' of self-destruction 'in-between'. In the process of getting to know ourselves, we realized that environmental problems, such as policies and institutions, and our problems, affected by social achievement and success, were mixed. Above all, we wanted to hear feedback that we were contributing to all the groups in which we belonged because it was important for us to be recognized as a teacher (ironically not as a counselor, but as a teacher who wants to be successful in counseling at the same time) and also ourselves at home. Although we recognized that this wish was not realistic, we could not accept that we can be emotionally insufficient or make mistakes. As we all know, however, it is impossible to be completely perfect, but we did not know at first that it was impossible. Just as Korean students suffer from private tutoring due to excessive achievement pressure from society and parents and thus experience academic burnout (Choi, 2012; Kim, 2013; Song, Han, 2015), those of us who faced them were also getting more and more exhausted psychologically and physically while struggling within the logic of excellence. We experienced the 'burn-out' that helping students with their emotional stability, growth, and development is sometimes no longer helpful either for them or for ourselves (Skovholt, 2001).

The inner question that guided us in this process was, 'Why do we have to be obsessed with becoming more capable?'. With these concerns, we gathered to find out what kind of person we are and what the identity of ' $\mathrm{I}$ ' as a school counseling expert is. At first, vaguely thinking that studying to get to know myself was the only a way to develop professionalism as a counseling teacher or counselor, we ran around here and there. Then, to get to know ourselves, we joined the dream symbol analysis and sandplay therapy group for our own growth. From there, we found out that our struggling and hard work was a process to find the 'mature me' who has a sense of work-family-leisure balance and knows how one's own needs are projected into work and life. We talked about our dreams and made impressive parts of the dream scenes in a sandbox using figures. And we talked about the associations between these things that came to mind.

In the process, we talked about the thoughts and feelings we felt in our various experiences, such as our pride, worries, conflicts, guilt, and identity confusion. Then we started talking about what we had learned when young at home and at school. The dreams we were educated about 
were: to be competent, to be good at everything, to be recognized, not to show shortcomings, and not to feel guilty about incompetence and shortcomings. And another thing was that we were under the illusion that we could achieve these things with our will, rational, and reasonable effort. This things may be useful as a teacher. However, counseling is not possible using only rational and reasonable will and effort. We did not learn how to balance work and our own lives, how to take a break, how to respect our own and others' feelings, how to live a life of mistakes, and how to live with our own inferiority. We learned how to hide or overcome our inferiority. However, we meet students who do not adapt well to school, students who are not interested in studying and are not doing well at school, students whose feelings are not respected, students who feel inferior and not recognized, students who cannot control or suppress their emotions, and students who are not loved by other students. In some cases, we meet children with only the identity of a teacher who wants to adapt students or clients to school and society without distinguishing whether we were teachers or counselors. During the counseling process, however, we also witnessed many times that students or clients have changed wonderfully and genuinely and exerted their own potential. In particular, through sandplay therapy which uses inner emotions and symbols rather than reason and thought in the counseling process, we discovered more potential and development possibilities of the clients that we did not know, or ignored, and as the sessions progressed, we looked at the possibilities objectively as we saw them recognizing themselves and the sand scene changing in a more positive way. I was able to naturally feel the therapeutic power of sandplay while making my own sandbox and receiving case supervision. I experienced both my growth as a counselor and the growth of my clients.

The confusion in the roles of school counselors is also caused by policies and realistic difficulties. A professional school teacher-counselor is a compound word made up of three words: professional, counseling, and teacher. The dictionary definition of a profession refers to a profession that requires specialized knowledge or skills (standard Korean dictionary), and a group of holders of specific licenses and certificates is called a profession. A profession refers to a job that must meet certain conditions such as a deep level of specialized knowledge, a sense of duty and ethics, autonomy and responsibility, and continuous development of professional ability (Choi Jae-jin, 2010). In this respect, teachers and counselors are professionals, and teachers and counselors are the same in that they help students grow internally, but different in that teachers 
Journal of Symbols \& Sandplay Therapy, Vol.12 No.2.

become the subject of student growth in order to realize goal-oriented values and change through education, while counselors help the client become the subject of their own life through counseling.

A professional school teacher-counselor is a person who holds the professional school teacher-counselor level 1 or 2 certificate among school counselors, and refers to a teacher who is appointed and assigned to the Wee center and Wee school of the city/province office of education, as well as the Wee class of elementary, middle and high schools, and is exclusively responsible for school counseling and related tasks. As of 2021, 3,785 professional school teacher-counselors are placed across the country. The three characteristics of the professional school teacher-counselor role model presented in the 2009 'Manual for the Operation and Activity of Professional School Teacher-Counselor' by the Ministry of Education, Science and Technology are: a. combined model of preventive and reactive services, b. goal-oriented school counseling model, c. model as an assistant. However, role performance conflicts can arise between the ideal counseling model and the reality of school life (Burnham \& Jackson, 2000), and of course, role performance is influenced by subjective role expectations and objective role expectations from outsiders (Kim Jung-suk, Yu Geum-ran, 2010; Secord \& Backman, 1964).

Counselors should not only play a role as a counselor, but also play various roles required by the special space of a school. In addition to counseling, school counselors are sometimes required to do administrative work, student guidance and act as social workers. This special situation causes school counselors to experience low self-esteem due to the lack of administrators, co-teachers, and parents' awareness of school counseling, and they are having difficulties in performing counseling-related tasks for students without the cooperation of general teachers, which leads to more exhausting emotional labor.

A qualitative study on the professional school teacher-counselor's professional identity formation process (Chae Hyun-soon \& Jang Yu-jin, 2016) showed that the central phenomenon in the professional school teacher-counselor's professional identity formation process was 'asking about my existence as a professional school teacher-counselor'. The study analyzed the process of linking the relevance between categories over time, and as a result, it was analyzed that participants form their identity through five stages: passion and ignorance, confusion and conflict, questions and concerns, practical struggle, and individual identity construction. Professional school teacher-counselors asked themselves the question of 'asking about my existence as a professional 
Jin Kim et al. / Auto-ethnography of Self-growth Stories for the Individuation of School Counselors (Professional Teacher-counselors and Professional counselors) Who Are Suffering from 'Between'-Based on Insight in Sandplay Therapy and Dream analysis-

school teacher-counselor due to difficulties such as self-awareness of lack of expertise in counseling, difficulties in the work environment, difficulties in communicating with many teachers and emotional isolation as a minority, others not understanding the specificity and professionalism of counseling, contemplating the meaning of existence to students, and shaky identity. In this regard, it can be seen that professional school teacher-counselors go through a common process such as intervention conditions including 'receiving support and emotional support', 'having a passion for school counseling', and 'experiencing a change in the awareness of people around them about counseling and professional school teacher-counselors' and various coping methods such as 'cultivating professionalism through the integration of knowledge and experience', 'creating a stable school counseling system', 'seeking changes in various systems and policies reflecting the needs of the field', and 'seeking adaptation at the individual level'. Feeling satisfied with being 'professional school teacher-counselors,' they endured frustration and burnout as their identity as school counseling experts was formed. According to the results of this study, however, professional school teacher-counselors are still in a situation where they have to endure frustration and burnout.

There is also a study reporting that professional school teacher-counselors experience role conflicts between home and work, and work and home (Lee Myung-rang, 2018). The study of Kim Jeong-suk and Yu Geum-ran (2010) showed that role conflict had a significant relationship with incompetence, and there was also a significant negative correlation between professional identity and burnout (physical fatigue, incompetence, uncooperative work environment, reduced value to clients, and deterioration of privacy). Even if the role conflict was high in the relationship between role conflict and burnout (physical fatigue, uncooperative work environment), those with high professional identity experienced less burnout.

There are various theories about the therapeutic function of dreams in counseling, analysis, or psychotherapy. From an analytical psychology perspective, however, dreams can be said to be meanings and images from the unconscious that reveal the important interests of the dreamer's mind, pursuing the wholeness of personality development. From an analytical psychology perspective, if the wholeness of personality development is continuously ignored, the individual will have psychological (sometimes including somatization) symptoms or conflicts, and the symptoms or conflicts at this time can be said to be the unconscious signal to achieve the wholeness of the personality. The unconscious communicates through images, i.e. symbols, rather 
Journal of Symbols \& Sandplay Therapy, Vol.12 No.2.

than the verbal communication method used by the conscious. Therefore, it is important to understand the meaning of symbols in order to understand the signals of the unconscious. Dreams are representative of the ways in which the unconscious sends images. Therefore, the dream analysis has a practical and therapeutic function (Jung, 1984/2001). The characteristics of dreams related to the past, present, and future of personal life evoke chronological recall or association (Jung, 1984/2001).

We have found that introspection or insight takes place in the process of talking about associations about dreams. In other words, it made us aware of the inner needs of each of us that our reason cannot identify but makes us suffer, and we came to realize the unconscious resources that can help us reach them. This is because dreams make themselves appear in the midst of the weakening of rational and conscious defenses. Dreams sometimes make us say and do things that we cannot say and do in real life, and sometimes reproduce in our mind unresolved problems in the form of real life, and reveal the dual or unconscious desires or characteristics that are inherent in us. There were many cases where I came to understand the meaning of parts I was not aware of while replaying the dream scene in the sandbox. In the process, not only will I know the meaning of my appearance in my present life, but it will also allow me to realize the attitude I need to take in the future to become an integrated and true self.

Although similar to dreams, one of the symbolic projection works of the unconscious in the waking state is sandplay therapy (Jang Mikyung, 2017). It is a visible work, but it is a work about the inner world. Even if an external event is expressed in the sandbox, it is not the event itself that occurred, but an event that has meaning for the person who expressed it. Through the work in the sandbox and verbal expression, we came to realize what was affected by the event and the personal, internal, and mental content that caused it, and came to understand how the personal, internal, and mental content is projected into and affected by the event. Also, as in dream work, the relationship between the conscious and unconscious is important in sandplay therapy. The reason for sandplay therapy is to integrate the unconscious into the conscious, expand the scope of the conscious, and renew the ego to achieve the wholeness of personality development. Symbols are used to make the unconscious conscious, and sand, sandboxes, and figures play a role as symbols (Jang Mikyung, 2017).

While directly experiencing dream work and sandplay therapy, we met our own unconscious 
and experienced complex emotions such as surprise, novelty, wonder, and discomfort. This experience made us face ourselves and even influenced the direction of our life for the future. Ultimately in this process, we learned how our own personal issues have dominated our lives, how they are intertwined with external realistic and institutional factors, and what position and attitude we should take in the process. Most importantly, through our own therapeutic experience, we were able to empathize and understand our client students more deeply.

Having a conversation with someone who understands and feels your own situation and position gives you peace of mind, and having someone like you gives you strength. In that sense, conversations with fellow counselors help a lot to organize emotions (Jin Hye-eun, 2014). Empathizing with each other's stories, we have learned that we have had very similar experiences and live similar lives. In the process, we came to think that we wanted to share our experiences and stories with the world, and we agreed to do a relay writing to attach the stories.

\section{Research Method}

\section{Auto-ethnography}

As research participants and researchers, the researchers of this study tried to find a way to present the experiences of multiple individuals and selected auto-ethnography as a result. Auto-ethnography is a qualitative research method that autobiographically composes the researcher's experience into a story, interprets it in a social, political, and cultural connection, and mainly describes the experience of the shared cultural self between self and others (Chang, 2008). In other words, auto-ethnography attempts to secure the validity of the contents revealed as a result of the study by unraveling the cultural context shared by oneself and others focusing on one's own story (Lee Hyun-jin, Kim Myeong-chan, 2017). In that aspect, the story of each individual researcher in this study is a story shared in the cultural context of school counseling experienced together.

Papers written in the auto-ethnography method are mostly written by one researcher and research participant. Since auto-ethnography refers to the story of past experiences or events 
Journal of Symbols \& Sandplay Therapy, Vol.12 No.2.

experienced by the author himself/herself in chronological order in a certain format, and is an approach to theoretically understand an individual's life while using a highly sentimental and private writing method (Kim Myeong-chan, 2013), we had a debate and discussion about whether the auto-ethnography approach applied in this study is appropriate. After that, a tentatively reached conclusion is that an auto-ethnography research approach is appropriate under the assumption that common reflective auto-ethnography will be possible with the individual experiences of multiple individuals, given that securing the validity and objectivity of a qualitative paper is achieved through intersubjectivity. Citing De Munck (2000), Kim Myeong-chan argures that, from the perspective of postmodernism, humans have no choice but to be interdependent in order to overcome their vulnerability and constitute themselves by relying on others (Kim Young-choen, 2013; Park Eun-young, Kim Myeong-chan, 2018). Individual subjective experiences and perceptions formed in this way are bound to reflect group experiences. These characteristics enable common experiences of 'we' among researchers/research participants composed of several people, and auto-ethnography can be said to be a suitable research method to show how our experiences are personal and common experiences of 'we' at the same time. As mentioned above, this is because the auto-ethnography method reveals the experiences shared between self and others in the social and cultural context in which the individual researcher experienced and lived through his/her autobiographic narratives. (Park Soon-yong, Jang Hee-won, Jo Min-ah, 2010).

Nevertheless, the auto-ethnography approach still raises questions about the validity or objectivity of the study. Citing related scholars, Park Eun-young and Kim Myeong-chan (2018) said that the data source of auto-ethnography is the use of the self, so the study has been criticized for being too self-tolerant and self-indulgent. As with most qualitative studies, the auto-ethnography method also presents the intersubjectivity that the researcher and the research participants commonly perceive and feel through the subjectivity of the researcher as the objectivity or validity of the research (Park Eun-young, Kim Myeong-chan, 2018). Intersubjectivity is a neurologically based concept, and Schore (2014) defined intersubjectivity as a state of knowing each other physically, implicitly, and unconsciously due to the interaction between the right brains of two people interacting. Intersubjectivity, a concept partially similar to intuition in analytical psychology and projective identification in object relational psychotherapy, is also an important concept in sandplay therapy (Jang Mikyung, 2017). 
Although not consciously or verbally expressed by the client, what the therapist and the client imagined in the sandbox can give many clues to the client's unconscious (Jang Mikyung, 2017). The third space called the sandbox allows complex energies such as attitudes, emotions, and beliefs to flow between the client and the therapist, and points of common feeling and perception can appear in this common space.

Intersubjectivity literally means understanding the other objectively through what is felt subjectively. That is why intersubjectivity in the counseling relationship is not only used as a basis for the validity of the auto-ethnography research method we will borrow, but also can be understood as a characteristic of sandplay therapy itself. In sandplay therapy, which emphasizes non-verbal intervention, the research participants had an experience of understanding each other's intersubjectivity while sharing their stories through the sandbox they worked on, sensitively noticing and sharing the emotions, imaginations, and associations derived therefrom.

This study can refer to intersubjectivity in terms of groups. Since there are multiple researchers/research participants, it can be said that they have the characteristic of proving intersubjectivity through mutual consensus. It showed that it is an individual experience and our experience at the same time. Auto-ethnography, which consists of one individual researcher/research participant, has the aspect of intersubjectivity with which readers must empathize, but this study experienced that intersubjectivity naturally existed in the process of sharing and discussing each person's experiences.

There are three main types of auto-ethnography (Reed-Danahay, 1997): The first is reflective ethnography, which emphasizes the reflection of researchers; the second is minority ethnography, which is recorded from the perspective of social minorities such as foreigners, women, and the disabled; and the third is auto-biographic ethnography, which analyzes an individual's experience in a socio-cultural context. Our story can be said to be closer to reflective ethnography in terms of analyzing our reflective experiences in psychological and social contexts as researchers and research participants. This study could be described as a minority auto-ethnography approach from the perspective of a counselor as a minority among many general teachers, but it was judged that the reflective auto-ethnography method would be more appropriate to reflectively describe the experience of oneself as a counselor and in social and cultural contexts. In this context, auto-ethnography enhances understanding of life, people, and society/culture, and although it is not the main goal of auto-ethnography (Kim Young-cheon, 2013), understanding 
Journal of Symbols \& Sandplay Therapy, Vol.12 No.2.

individual and social/cultural influences through the process of understanding individual life and society/culture broadens the view of oneself and others, which is judged to bring about a healing effect. Using auto-ethnography to enable research participants to tell their own stories and do cultural analysis to help them realize their own self will help expand self-awareness as a counselor and enhance competence as an expert. In this study, we, researchers/research participants, looked back on our experiences and lives in the process of writing a thesis, as well as a group experience for self-analysis and understanding. It can be said that the process of looking back on them in the context of others and social/cultural contexts was more active, and in the process, deeper insights and broader perspectives were obtained, which brought a healing function.

\section{Research Participant}

The research participants were 9 professional school teacher-counselors and 2 professional school counselors from Seoul and Gyeonggi Provincial Offices of Education. The research participants belonged to Wee Center, elementary school, middle school, and high school, and one professor who led the sandplay therapy workshop, dream symbol analysis, and group participated as a co-researcher. <Table $1>$ below presents the personal information of the research participants. Among the personal information, counseling-related qualifications were limited to sandplay counselors and national licenses.

\section{Research Procedure}

Researchers/research participants participated in a 12-hour group dream symbol analysis and 100-hour sandplay therapy workshop, and conducted one individual interview with a group leader. This course lasted from April 6, 2019 to November 29, 2020. Since there are more than two researchers, all researchers jointly conducted from topic selection, data collection and description, data analysis and selection of theories, analysis and classification of categories, and proposals for research results. In all of these processes, there were frequent discussions among the co-researchers, as well as agreeing, supplementing, and subsequent writing. As a specific narrative method, confessional-emotive writing was performed focusing on subjective emotions 
Jin Kim et al. / Auto-ethnography of Self-growth Stories for the Individuation of School Counselors (Professional Teacher-counselors and Professional counselors) Who Are Suffering from 'Between'-Based on Insight in Sandplay Therapy and Dream analysis-

Table 1. Personal information of research participants

\begin{tabular}{|c|c|c|c|c|c|c|c|c|}
\hline Order & Participant & $\begin{array}{c}\text { Establishment } \\
\text { Category }\end{array}$ & Place of work & Gender & Age & $\begin{array}{l}\text { Counseling } \\
\text { experience }\end{array}$ & $\begin{array}{l}\text { Qualifications related } \\
\text { to counseling }\end{array}$ & $\begin{array}{l}\text { Educational } \\
\text { background }\end{array}$ \\
\hline 1 & Teacher A & Public & $\begin{array}{l}\text { OO Elementary } \\
\text { School }\end{array}$ & $\mathrm{F}$ & 31 & $\begin{array}{l}8 \text { years and } \\
2 \text { months }\end{array}$ & $\begin{array}{l}\text { Professional School } \\
\text { Teacher-Counselor level } 1 \\
\text { Youth Counselor Level } 3\end{array}$ & $\begin{array}{l}\text { Master's } \\
\text { program }\end{array}$ \\
\hline 2 & Teacher B & Public & OOWee Center & $\mathrm{F}$ & 38 & $\begin{array}{l}3 \text { years and } \\
5 \text { months }\end{array}$ & $\begin{array}{c}\text { Professional School } \\
\text { Teacher-Counselor level } 1 \\
\text { Sand Play Counselor Level } 2\end{array}$ & $\begin{array}{c}\text { Master } \\
\text { graduation }\end{array}$ \\
\hline 3 & Teacher C & Public & $\begin{array}{l}\text { OO Elementary } \\
\text { School }\end{array}$ & $\mathrm{F}$ & 36 & $\begin{array}{l}9 \text { years and } \\
1 \text { month }\end{array}$ & $\begin{array}{l}\text { Professional School } \\
\text { Teacher-Counselor Level } 1 \\
\text { Youth Counselor Level } 2 \\
\text { Sand Play Counselor Level } 1\end{array}$ & $\begin{array}{c}\text { Master } \\
\text { graduation }\end{array}$ \\
\hline 4 & Teacher D & Public & $\begin{array}{l}\text { Elementary } \\
\text { School }\end{array}$ & $\mathrm{F}$ & 33 & $\begin{array}{l}2 \text { years and } \\
5 \text { months }\end{array}$ & $\begin{array}{c}\text { Professional School } \\
\text { Teacher-Counselor Level } 2\end{array}$ & $\begin{array}{c}\text { Master } \\
\text { graduation }\end{array}$ \\
\hline 5 & Teacher E & Public & $\begin{array}{l}\text { Elementary } \\
\text { School }\end{array}$ & $\mathrm{F}$ & 59 & $\begin{array}{l}9 \text { years and } \\
5 \text { months }\end{array}$ & $\begin{array}{c}\text { Youth Counselor Level } 2 \\
\text { Clinical Psychologist Level } 2 \\
\text { Professional School Counselor } \\
\text { Level } 2\end{array}$ & $\begin{array}{c}\text { Master } \\
\text { graduation }\end{array}$ \\
\hline 6 & Teacher F & Public & O Middle School & $\mathrm{F}$ & 35 & $\begin{array}{l}3 \text { years and } \\
8 \text { months }\end{array}$ & $\begin{array}{l}\text { Professional School } \\
\text { Teacher-Counselor Level } 1 \\
\text { Youth Counselor Level } 2\end{array}$ & $\begin{array}{c}\text { Master } \\
\text { graduation }\end{array}$ \\
\hline 7 & Teacher G & Public & O Middle School & $\mathrm{F}$ & 46 & 10 years & $\begin{array}{c}\text { Professional School } \\
\text { Teacher-Counselor Level } 2 \\
\text { Youth Counselor Level } 2 \\
\text { Clinical Psychologist Level } 2 \\
\text { Sand Play Counselor Level } 1\end{array}$ & $\begin{array}{c}\text { Master } \\
\text { graduation }\end{array}$ \\
\hline 8 & Teacher H & Public & OO High School & $\mathrm{F}$ & 51 & $\begin{array}{l}9 \text { years and } \\
4 \text { months }\end{array}$ & $\begin{array}{c}\text { Youth Counselor Level } 2 \\
\text { Clinical Psychologist Level } 2 \\
\text { Sand Play Counselor Level } 1\end{array}$ & $\begin{array}{l}\text { Ph.D. } \\
\text { program }\end{array}$ \\
\hline 9 & Teacher I & Public & OO High School & $\mathrm{F}$ & 34 & $\begin{array}{l}5 \text { years and } \\
5 \text { months }\end{array}$ & $\begin{array}{c}\text { Professional School } \\
\text { Teacher-Counselor Level } 2 \\
\text { Youth Counselor Level } 2\end{array}$ & $\begin{array}{c}\text { Master } \\
\text { graduation }\end{array}$ \\
\hline 10 & Teacher J & Private & O High School & $\mathrm{F}$ & 55 & 5 years & $\begin{array}{c}\text { Professional School } \\
\text { Teacher-Counselor Level } 1 \\
\text { Clinical Psychologist Level } 2 \\
\text { Youth Counselor Level } 2 \\
\text { Sand Play Counselor Level } 1\end{array}$ & $\begin{array}{c}\text { Master } \\
\text { graduation }\end{array}$ \\
\hline 11 & Teacher K & Public & O High School & $\mathrm{F}$ & 44 & $\begin{array}{l}11 \text { years } 5 \text { and } \\
\text { months }\end{array}$ & $\begin{array}{c}\text { Professional School } \\
\text { Teacher-Counselor Level } 1 \\
\text { Youth Counselor Level } 2 \\
\text { Sand Play Counselor Level } 1\end{array}$ & $\begin{array}{l}\text { Ph.D. } \\
\text { program }\end{array}$ \\
\hline
\end{tabular}


Journal of Symbols \& Sandplay Therapy, Vol.12 No.2.

(Kim Young Cheon, 2013, Park Eun-young, Kim Myeong-chan, 2018; Chang, Ngunjiri \& Hernandez, 2013). Even after sandplay therapy, dream symbol analysis and the work were finished, ideas and impressions that came to mind were continuously shared through SNS, and the entire process of writing the thesis was also shared.

\section{Data Collection and Rigorousness of Research}

The data used in relation to the research topic are as follows:

- Memory data: Dreams and dream associations, associations with sandplay therapy, related life events and experiences;

- Sand scene pictures;

- Introspection data: Contemplation, recollection, consciousness, insights, etc.;

- Observation data: Observations of researchers/research participants;

M- Sharings on group SNS;

- Individual interviews, others

The analysis data used in this study were extracted from a total of 1,530 data. The types of data are memory data for triangular verification, picture data, self-reflection data, observation data, sharings by group, and interview data. The memory data includes 12 hours of group dream symbol analysis from April 6, 2019 to November 29, 2020, in which researchers/research participants participated for self-analysis, which is essential for counselors, self-experience in 100 hours of sandplay therapy workshop, dream symbol analysis, dream content in work, association about dream content and sandbox, and life experiences and events. All sessions were recorded and the sandboxes were photographed. The picture data is the pictures of sand scenes made by each person in a sandplay therapy workshop. Each has a total of 156 pictures. The self-reflection data included comments on contemplation, recollection, imagination, and insights about each person's experiences and lives that he/she remembered or thought about in addition to sandplay therapy and dream work. The observation data is based on the observations of the researchers/research participants who participated in the sandplay therapy workshop, dream symbol analysis, and work together. This observation included comments to each other's process of change and joint reflection. In addition, sandplay therapy, dream symbol analysis, and 
individual interviews after the work were included.

The parts judged to have contributed to securing the validity of the study are as follows: First, the transcripts of each participant's comments and the entire contents of the result analysis were presented to the research participants and received feedback; Second, feedback based on the transcripts and observations contributed to reducing errors in the data of each research participant; Third, in order to find an explanation that supports the result analysis, we tried to support it with research papers and previously developed theories; and finally, professional opinions were sought from one professor from another major not included in the study.

\section{Consideration of Ethics}

In auto-ethnography, the researchers and research participants' problem of 'self-exposure is inevitable, but the protection of research participants in terms of research ethics for humans' is inevitable (Kim Myeong-chan, 2015). In this regard, 'relational ethics' for the auto-ethnography research method was suggested as an alternative to the existing research ethics (Kim Myeong-chan, 2015; Ellis, 2007). According to Kim Myeong-chan, relational ethics should be conducted based on 'closeness' and 'mutual trust and respect' between the researcher and research participant in the research process, and there should be alternatives in case the research process brings negative reactions. It followed the argument of Kim Myeong-chan (2015) that recognizing the negative results that the research process can bring and removing them, and that 'process contents' for the specific research process rather than consent for the whole research could be an alternative. In addition, measures were taken to prevent the exposure of personal information of the research participants or the information of those around the research participants. Through continuous dialogue between researchers/research participants, we continued to discuss ways to maintain the purpose of the study without exposing sensitive information about researchers/research participants or information about people around the researchers/research participants. In addition, consensus was reached on confidentiality obligations and exceptions for information shared among research participants. 
Journal of Symbols \& Sandplay Therapy, Vol.12 No.2.

\section{Results: A Journey to Finding Occupation and Life Identity}

Identity is a concept composed of several factors, among which personal identity about work and life itself is an important factor that meets mission for a specific job and personal needs and sustains a positive life (Erikson, 1994). At the same time, occupation and personal life are harmonized and integrated holistically, but they also cause conflicts and cause the individuals to fall into conflict, losing enthusiasm for both parts. However, the harmony and integration between the two factors are gradual, and environmental and personal factors interact. It is judged that our journeys as professional school teacher-counselor and professional school counselor is also following this path. The element between the two contains growth and individuation within an individual and a group.

\section{Dreaming}

We, as those who were subject teachers or counselors, or those who were appointed as counselors from the beginning, passed through the gate with difficulty, with the determination to help children who are struggling as professional school teacher-counselors or professional school counselors. We started our 'profession' with a 'dreaming (aspiration)'. We had a blue dream 'if I did something, the children would get better'.

\section{[2019.9.21. Sandplay therapy workshop]}

I was always very interested in counseling. When in high school, I was engaged in a counseling club, and I had a dream of choosing it as my college major..., and I feel grateful for having achieved what I wanted to do in society (Research participant A).

This is a dream of my (university) graduation ceremony. When I receive my diploma, my dad is holding my luggage and congratulating me in the back seat. When I became a counselor, he liked it and was delighted very much.... I started counseling with the desire to help my friends in need. I think I provide counseling at school with my own expertise... (Research participant C) 


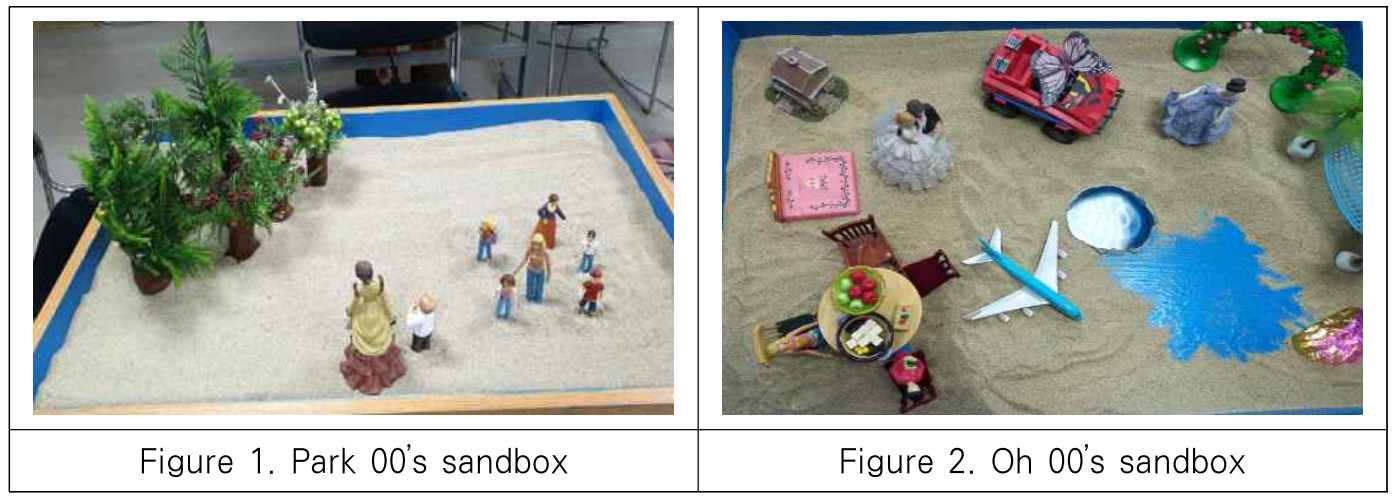

\section{Stumbling and frustration: self-blame and resentment}

We, who started our profession with the dreaming, could not avoid the experience we faced in reality. We thought we knew that the ideal and reality were different, but the reality we faced was different than we expected. I was alone and there were no colleagues at school with whom I could share my work and concerns. It was more difficult for me to inform general fellow teachers and managers about the nature of one-on-one counseling and counseling that requires confidentiality. It even made me feel left out. It was an inexplicable feeling of alienation, and sometimes it was connected to personal issues, leading to a feeling of inferiority, a sense of shame, and even a sense of self-blame for not being able to fulfill the duties due to lack of ability. In dealing with children with broken families, severely traumatized children, and even children with suicidal impulses, as well as children who do not adapt in the classroom, I even felt terrified. There were times when we were literally surrounded by feelings of stumbling, frustration, self-blame and resentment. Without distinguishing between individual issues and system problems, we talked about system problems, but deep within, we were criticizing our own incompetence and inferiority. We have been educated to do well, to be acknowledged, and to be better than others. Unfortunately, however, we also suffered from the guilt of not providing real help to children without even knowing what needs to be fixed. This feeling of guilt extended to the family as well. The personal issue of wanting to be recognized for being more perfect and good extended to the family and made us try to become good spouses and good parents. In the end, the feeling of guilt for not being good to even our family made our life exhausting and difficult. At the same time, we did not even have the question, 'Who is 
Journal of Symbols \& Sandplay Therapy, Vol.12 No.2.

this life for?'

[2019.10.9 Sandplay therapy workshop and 2020.7.-8. dream symbol analysis, work]

I have no one to ask what to do. I asked other school teachers and held the event, but the principal and other teachers didn't even notice how I did it, they don't seem to care, and I think they take it for granted. Since I'm just saying the wrong thing, I think I'm incompetent... . I don't know what the other teachers do (Research participant B)

In the same grade at school, I work with a health teacher, a nutrition teacher, and two special education teachers, a non-homeroom teacher and non-subject teacher teachers. So when we talk, they have a lot to talk about in common, but no one knows what we're doing, which is sad. So, the feeling that I am not the part of the group gives me a feeling of being like a pioneer... I think I feel so lonely. (Research participant $K$ )

When I concentrate on school work, I feel sorry for and worry about the children at home. Then, because of this, I am so tired. (Research participant E)

I went here and there to study. I think other people are so good at it... I thought I would develop my skills if I got more certificates. (Research participant F)

Why are there so many things to study... I hate my husband, who doesn't help me. (Research participant D)

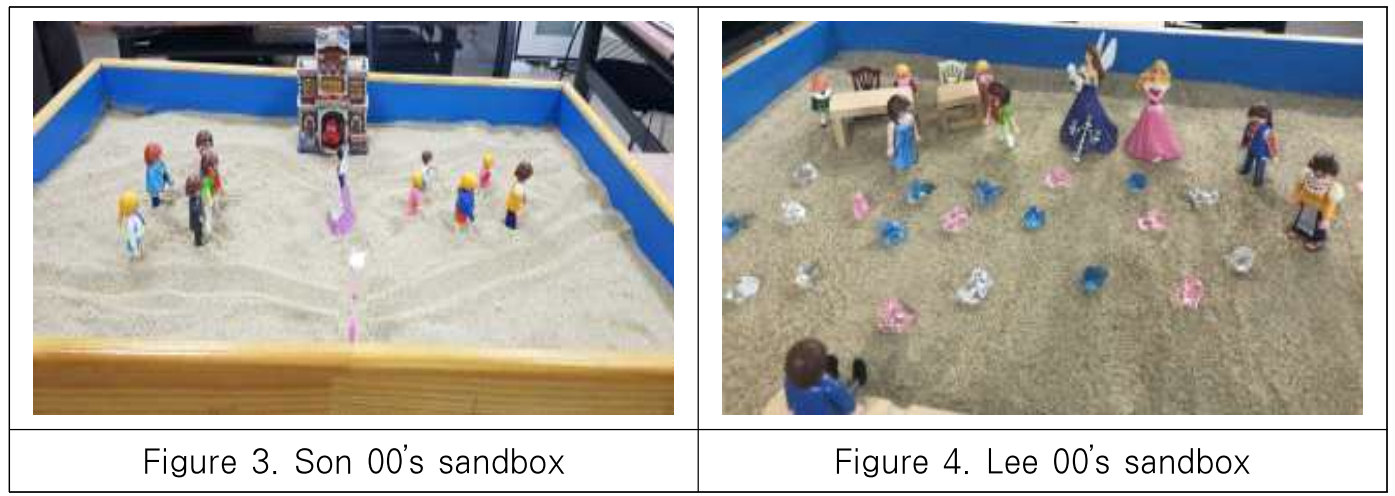




\section{Searching for breakthrough: Finding identity}

So we set out to find a way to fill our shortcomings, our feelings of inferiority, our incompetence, and the confusion that something was wrong. While experiencing and learning many things, we came to sandplay therapy, dream symbol analysis, and work, and wanted to know how our own problems and the problems of our situation are working within us. Born and lived in our culture and society, we realized how much we have been tormenting ourselves with one-sided values of success, achievement, and recognition.

[2019.4.6.-2020.6.21. Sandplay therapy workshop and 2020.7.-9. dream symbol analysis, work and 2020.12.27.-12.28. interview]

\section{1) Sandplay and dream: Encounter with the inner world}

This was the process of listening to our inner voice as to what made us struggle so much. We came to realize that culture has driven us, saying that success, achievement, and recognition are the only ways to live well, and now our internalized inner voice has driven us.

I think I got to know myself through this work (Research participant A)

There are some things that are naturally resolved over time. Should I call it leisure? I also think that professionalism comes from leisure. Leisure to life, leisure for myself, leisure for others, leisure for my abilities... With those thoughts in mind, I feel like I want to work hard this year and pass on what I have learned to my children. (Research participant B)

I didn't know I had the mindset for doing so well. If my boss or co-workers don't seem to give me good feedback, I feel like I'm distant from that person and they don't seem to recognize me. School life was hard. (Research participant D)

Dream symbol analysis is an amazing experience. When I was making the sandbox, I didn't even think about my mother at all, but in the end everything returned to my problem again. (The professor) pointed at me trying to escape, and talked about a figure that seemed to represent my startled mother, and said that my hand already knew and put her there, which impressed me. 
Journal of Symbols \& Sandplay Therapy, Vol.12 No.2.

Thank you for giving me a good experience. (Research participant C)

I thought that I should respect, cherish, and take care of myself a little more. It made me look back on things I knew but neglected. (Research participant G)

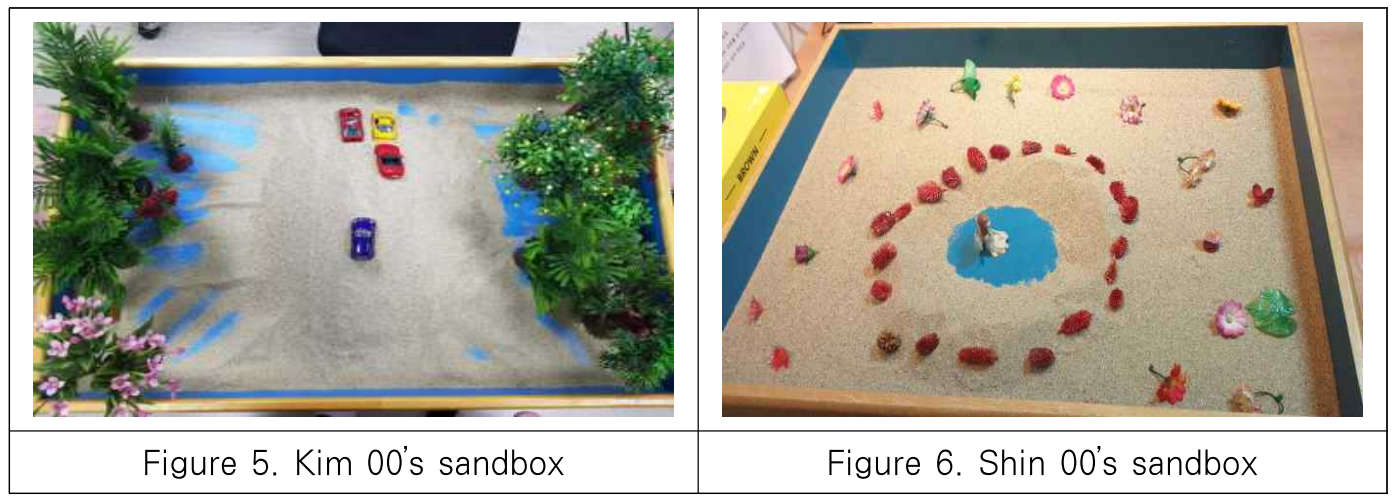

\section{2) Wrestling with regrets for children}

We also had to wrestle with counseling children. We wrestled with the obsession to succeed at counseling, and wrestled with the pain that children innocently endure because of their situation.

There are children who pour water into broken jar because of the wide spectrum of problems of the client students, so despite the connection with an external organization, it doesn't last long because of the cost... Limitations that cannot be covered as a counselor... A sense of shame about the quality to catch problems quickly and help... Even if I share their problems with a general teacher, their view itself is different, so I am in a position where I have to protect or defend the students. Sometimes I have to act as a parent. I am very sorry. I am confused about my role. How much I should cover? (Research participant H)

I provided counseling with the sandbox throughout one session, which made me so proud... I got language counseling training first and it was so ingrained in my body that I was going to have language counseling even if the flow stopped while doing sandplay. When I did it in early December, I did it all in the sand, which was so good. I felt the child expressing himself through symbols. It's sad... He didn't say much, but I felt the child expressing himself through 
Jin Kim et al. / Auto-ethnography of Self-growth Stories for the Individuation of School Counselors (Professional Teacher-counselors and Professional counselors) Who Are Suffering from 'Between'-Based on Insight in Sandplay Therapy and Dream analysis-

symbols. (Research participant $J$ )

It happened at that school before 2019, and during counseling, I had to meet the parents. But the parent's problem was so serious. So, in order to help the child, I had to tell this parent that something is wrong. In other words, I had to make them face it. Yes, but that (parent counseling) was very difficult. (Research participant K)

As I discovered for myself as a child, I realized that I always wanted to do something for my clients and wanted to help them. When I found out how it really is, I cried a lot. As I experienced that, I thought that I, who think I have lived a smooth life, have difficulties too, but how difficult it would be for clients who seem to be having such a hard time. I was embarrassed because I never thought I would have such an experience. If only I had known this... Regretful and sorry... (Research Participant I)

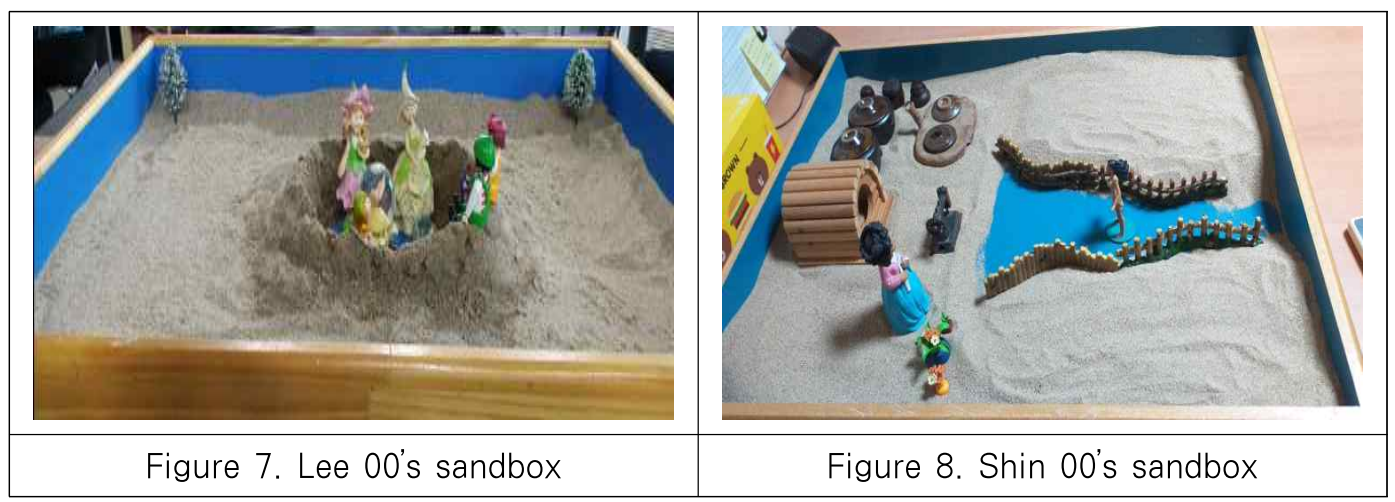

\section{Accepting incompleteness, which are still in progress}

Despite the worries so far and the many studies and efforts for which we have been running, we came to accept that all environments, groups, institutions, and individuals are imperfect. We also came to accept the incompleteness that exist in personal life to some extent. However, we did not abandon our professional determination to change the system and society for the sake of our children and ourselves. 
Journal of Symbols \& Sandplay Therapy, Vol.12 No.2.

[2019.4.6.-2020.6.21. Sandplay workshop/2020.7.-9. Dream workshop/2020.12.27.-12.28. interviews]

It made me keep thinking about my dramatic side. The idea that a balance in the two areas is important... I try to control the past pattern, that is, my moral and rational self.. When I am not like that, I think it's okay, and I feel more relaxed when I think that this is me... The same goes for my client students. It lets me see the other side. In cases of self-harm or suicide, I knew that the student had a strong will to live and explained that he wanted to commit suicide because he had a strong will to live. I also had a point of view where I tried to see what was not seen in the child. It seems that there is an attitude to try to balance things. (Research participant F)

I think it was mysterious and a great experience when I saw the growth process that Calf or Neuman in the book talked about during sand counseling with the client children... So I have more faith in the natural development and change by following what the children do. (Research participant $G$ )

Due to the specificity of school counseling, there is a problem with identity when I receive external supervision, and I am comfortable and grateful that my supervisor understands this part. New teachers get confused because the reality is different from what they learned at school... There must be a school counseling method related to those things. (Research Participant I)

I realized that I was living a one-way life. It makes me think about my husband's situation... I would say my life became healthier. In the past, I thought of filling shortcomings, obsession that I have to study and learn morc $\cdots$ After realizing that, I feel the preciousness of my family, my husband, and everyday life, and more that I have missed because of it. I had asked my husband to take care of our babies more and to give me more support for my outside activities... My husband must also have difficulties... (Research participant $J$ )

In this sandplay therapy education, I came to understand myself through the counter transitive part. Counseling became more relaxing... I was doing counseling for teenagers, and I found out what kind of mindset I have about students, and thinking that those student's friends have a positive mindset that they can do well and want to do well, I tried too hard and do too much of something... As a result, empathy, acceptance, and leisure were rather lacking. I would say that I 
Jin Kim et al. / Auto-ethnography of Self-growth Stories for the Individuation of School Counselors (Professional Teacher-counselors and Professional counselors) Who Are Suffering from 'Between'-Based on Insight in Sandplay Therapy and Dream analysis-

have gained trust in my clients (Research participant A)

When I think about the reason I wanted to study in various fields, it is because I had to deal with learning, mental health, maladjustment, and social welfare (at school). Not thinking about them, I only thought that I was not good enough personally, and I was having a hard time studying here and there. Because I only thought from the point of view that I was not good enough... (Research participant $G$ )

After experiencing sandplay therapy firsthand, I used it for elementary school students, and when I used it as an educational method for students and parents of students who committed school violence, they came to understand each other. Even without interpretation, there is a process where parents understand their children by looking at the atmosphere and think about their feelings, and the children understand their parents. After getting a license, I had the courage to use sandplay therapy on teachers who needed it, and they liked it very much. It was also good to approach children who were reluctant to speak at the beginning of counseling... (Research participant C)

Before participating in the sandplay therapy training course, I was a counselor who was curious about what happened to the client rather than empathizing with him/her. After I started practicing sandplay therapy, there was a change in my attitude to focus on what kind of mindset my client had rather than what happened to him/her. Before studying sandplay therapy, there was a time when I went to various educational disciplines and tried to come up with my own theories while talking to the counselors about what theories they have... But now I have an attitude where I listen more to clients. (Research participant D)

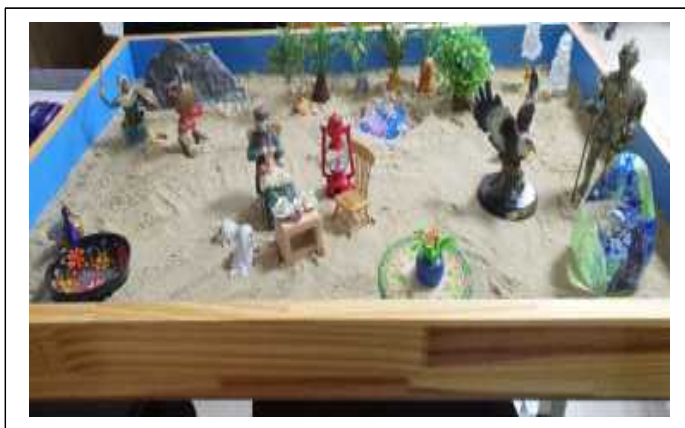

Figure 9.

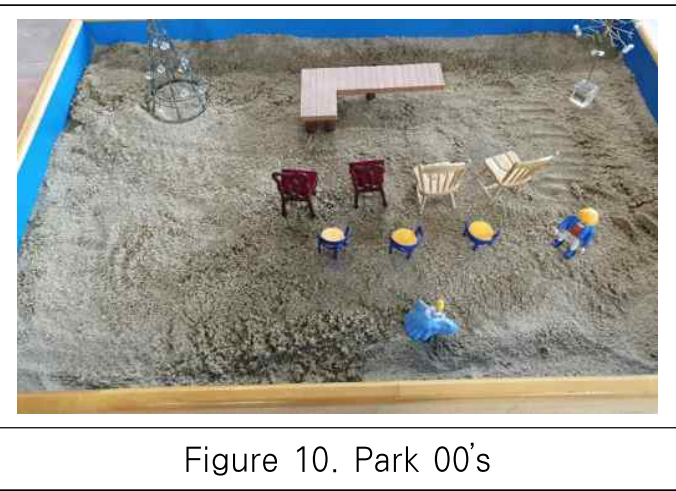


Journal of Symbols \& Sandplay Therapy, Vol.12 No.2.

\section{Conclusion and Suggestions}

This article aims to provide auto-ethnography for self-growth and individuation through the experience of applying sandplay therapy to school counseling of 11 professional teacher-counselors and professional school counselors, changes in the counseling effect, and the counselors' own sandplay therapy and dream symbol analysis. The difficulties as a school counselor, frustration and effort, and some implications found in the process of searching for breakthrough are as follows:

First, we shared the difficulties of being in school with a sense of balance as a counselor due to the specificity of school counseling. We were experiencing confusion about work and role conflicts between teachers and counselors, and these conflicts and frustrations were attributed to lack of individual competence or resentment against the environment. For example, we blamed our inferiority or incompetence on the thought of success or achievement, resented our spouses or parents for not helping them to fully utilize our abilities, or resented general teachers and administrative leaders who made their own group and did not seem to recognize us. On the one hand, we recalled how we worked tirelessly to study in good schools to fill our inferiority and shortcomings. And we realized how easily a school counselor exposed to the various barriers of a school counseling environment was in a position or environment where we could only wind up exhausted. Achieving consensus through the sandplay therapy workshop and dream symbol analysis, we realized that all of these were experiences of each of us as well as our experiences. Through the process of sand scene making and dream symbol analysis, personal problems came to the surface, and the process of sharing and comforting individual problems became an experience to accept incompleteness. We were able to look back on our experiences and lives. Furthermore, we were able to look back on them in other people's social/cultural context. In the process, we gained deeper insights and broader perspectives, found our identity as a professional school teacher-counselor and professional counselor, and realized that this brought healing. In addition, through this sharing, professional school teacher-counselors and professional counselors recognized that they are currently in a situation where they should endure frustration and burnout, and realized that they needed courage to face difficulties. 17 years have passed since the placement of professional school teacher-counselors dedicated to school counseling in September 2005. Now, school counselors must establish their own identity and become the 
subject of school counseling.

Second, through the academic understanding of sandplay therapy, the attitudes and mindsets as a counselor were changed, and we experienced that it greatly affected the counseling capacity. The inner unconscious parts, which the client was not aware of or did not express in words, were projected in a sandbox and revealed as symbols. By sensitively noticing the emotions, imaginations, and associations derived from this, we had the experience of understanding each other's intersubjectivity while sharing together. The direction of sandplay therapy work is to integrate the unconscious into the conscious to expand the scope of the conscious and renew the self to achieve the wholeness of personality development. Symbols are used to make the unconscious conscious, and sand, sandboxes, and figures play a role as symbols. Just as a teddy bear or a warm blanket helps to gradually separate a child from the mother while establishing a relationship as an intermediate object in the object relation theory of Winnicott (recited from 1971, Jang Mi-kyung, 2018), the sandbox served as an intermediate zone for healing and growth. In the school counseling scene where there may be the risk of multiple relationships, transfer and countertransference could be addressed more safely through the sandbox. We experienced that it could be used as a good counseling method for children and adolescents who are not aware of it or cannot express it in language. Also, watching the changing process of the sandbox, we were able to see and feel the changes in children and adolescents with our own eyes.

Finally, this article has value and important significance as a field study, in that it reflects the sincere stories of 11 professional school teacher-counselors and professional school counselors who experienced the reality of school counseling.

In school counseling, there are many external problems that are difficult to improve using only the efforts of professional school teacher-counselors and professional school counselors. We would like to offer some suggestions so that the realizations we have gained and the hopes we hold for our young clients can become the basis for our future reality.

First, our auto-ethnography study made us recognize that school counselors are experiencing role conflict and confusion in the 'between' phenomena due to the specificity of school counseling. In a school environment that shakes and tests professional counseling, school counselors have struggled on their own, protected their clients, and maintained the school counseling field. Although recognition is gradually improved through the individual efforts of 
Journal of Symbols \& Sandplay Therapy, Vol.12 No.2.

many school counselors, efforts to improve recognition from a more macroscopic point of view should be accompanied. There should be education to improve the awareness of school administrators and general teachers about the reason and importance of the school counseling space becoming 'Temenos' where confidentiality is guaranteed and changes in in the inner world and life of young clients should be made without interruption, in a delicate way.

Second, the sandplay therapy work and dream symbol analysis allowed all 11 researchers to find 'us' maturing by being aware of and reflecting on 'bias' and 'balance'. The early method of instructing and educating students in the past still remains in the school counseling field. A client-centered counseling approach will be needed in order to advance to a counseling suitable for the new paradigm of new education rather than one-way advice or suggestion. In addition, we hope that various theories and psychotherapy techniques such as child-centered counseling including sandplay therapy or play therapy will be flexibly introduced and applied to the school counseling scene in order for school counseling to move from the bias of the language-biased counseling approach to more specialized counseling.

Third, training regulations for school counselors need to be addressed within laws and systems such as the school counseling law or the counseling ordinance. There is confusion with the concept of class opening in counseling scholarship in front-line school settings, and clear guidelines are needed in teacher evaluation and the operation of the professional learning community as the professional counseling field. Furthermore, in order to develop the professionalism of professional school teacher-counselors and professional school counselors and manage the quality of professional counseling, guidelines for continuous self-check through educational analysis, training, and supervision (scholarship) are needed. This also means that an environment guaranteeing the unique job and independence of professional counseling should be established based on an understanding of professional counseling.

The special counseling setting of the school, the understanding of the professionalism of counseling, and proper training and assurance of identity will be a cornerstone for providing more focused and professional counseling services to future leading persons by preventing the burnout of school counselors, forming a clear professional identity, and balancing the personal life and work of individual school counselors. These suggestions also suggest the need for additional research and policy changes based on what we realized and felt during the research process. We sincerely hope that professional counseling within the school will be consolidated 
and that it will eventually become the foundation for the discovery and growth of our children's dreams and potentials out of the old perceptions and frameworks of the past.

\section{References}

Ministry of Education, Science and Technology (2021). The status of placement of professional counselors nationwide. Materials provided to the 2021 National Audit.

Ministry of Education, Science and Technology (2009). Working manual for professional teacher-counselors.

Kim, K. H. (2013). Role of academic control in the relationship between academic burnout and parental achievement pressure: using latent growth model. Korea University Graduate School of Education. Master's thesis.

Kim , Y. C. (2013). Qualitative research methodology 2-Methods. Academy Press: Seoul.

Kim, M. C. (2015). An autoethnography on the recovery of 'Wounded Father and Son'. Journal of Anthropology of Education, 18(4), 85-120.

Kim, I. G. (2012). A Study on developmental plan of school counseling. Journal of Educational Research, 10(3), 235-256.

Kim, Ingyu., \& Jo, Nam Jeong. (2010) Job analysis of school counseler using DACUM method. The journal of Korean Teacher Education, 27(2), 97-115.

Kim, J. S., \& Yu, K. L. (2010). A Moderating effect of professional identity for the professional school counselors in the relationship between role conflict and burnout. Korean Journal of Counseling And Psychotherapy, 22(1), 53-69.

Kim, J. Y., \& Kim, D. I. (2015). Work adjustment process of professional school counselor. Korea Journal of Counseling, 16(1), 73-93.

Kim, J. J., \& Lee, Y. S. (2015). The Process of Adaptation as the Professional School Counselors. Korean Journal Of Counseling And Psychotherapy, 26(2), 223-246.

Park, K. Y., \& LIM, E. M. (2014). The study of concept mapping about experience of burnout of professional school counselors. secondary education research, 62(1), 171-198.

Park. E. Y., \& Kim. M. C. (2018). Collaborative autoethnography on memory formation and transformation process, as a relational representation. Journal of Qualitative Inquiry, 4 (2), 97-129.

Park, S. Y., Chang, H. W., \& Cho, M. A. (2010). Autoethnography: exploration of its value as a research methodology in anthropology and education. Journal of Anthropology of Education, 13(2), 
Journal of Symbols \& Sandplay Therapy, Vol.12 No.2.

55-79.

Song, M. R., \& Han. G. B. (2015). Effects of Parenting Attitudes Perceived by Science High Schoolers on Subjective Well-being: Mediating Roles of Academic Self-Efficacy and Peer Relationships, Korean Journal of Youth Studies, 22(4), 93-111.

Lee, M. R. (2018). Effect of work-family conflict and family-work conflict on the burnout of school counselors: Focusing on cognitive flexibility and stress coping methods. Korea University Graduate School of Education. Master's thesis.

Lee, J. W., \& Oh. I. S. (2016). Phenomenological study on a school counselor`s professional development experience. Korea Journal of Counseling, 17(4), 351-372.

Lee, S. M., \& Ahn, S. H. (2003). What should the school counselor do?. Korea Journal of Counseling, $4(2), 281-293$.

Lee, H. A., \& Lee, K. H. (2009). The Relationship among job stress, job satisfaction, and burnout of the professional school counselors. The Korean Journal of School Psychology, Q1), 83-102.

LEE, H. J., \& Kim, M. C. (2017). Autoethnography on complex-trauma experiencer's child rearing experiences. Journal of Qualitative Inquiry, 3(2), 329-353.

Jang, M. (2017). Analytical psychological sandplay therapy. Seoul: Hakji-sa.

Jang, M. (2017). Play therapy. Seoul: Changii-sa.

Jung. H. K. (2015). The Development and validation of the competencies scale of school counseling teachers. Graduate School of Kyungsung University. Doctoral dissertation.

Jin, H. E. (2014). Qualitative Study on Emotional Labor of Professional Counseling Teachers. Graduate School of Woo Seok University. Master's thesis.

Chae, H. S., \& Jang. Y. J. (2016) A Qualitative study on the process of school counselors' professional identity formation. Journal of Korean Teacher Education, 33(4), 167-192.

Choi, D. H. (2012). Effect of school achievement pressure on academic achievement: Focusing on the discriminatory effects of socioeconomic background. Korea University Graduate School. Master's thesis.

Choi. J. J. (2010). A Study on teachers' perception of the teacher salary system which reflects professional characteristics. Graduate School of Korea National University. Doctoral dissertations.

Korean Education Development Institute (2011). Research on ways to improve the counselor qualification system: Focusing on school counseling. CR2011-36.

Han, A. L., \& Oh, I. S. (2014). The Moderating effect of emotional intelligence in the relationship between school counselor's job stress and burnout. Korean Journal of Teacher Education, 3022), 227-251.

Burnham, J. J., \& Jackson, C. M. (2000). School counselor roles: Discrepancies between practice and existing 
models. Professional School Counseling, 4(1), 41-49.

Chang, H. (2008). Autoethnography as method. Walnut Creek, CA: Left Coast Press, Inc.

Chang, H., Ngunjiri, F. W., \& Hernandez, K. C. (2013). Collaborative autoethnography. Walnut Creek,

CA: Left Coast Press, Inc.

Ellis, C. (2007). Telling secrets, revealing lives: Relational ethics in research with intimate others.

Qualitative Inquiry, 13(1), 3-29.

Erikson, E. (1994). Identity and the life cycle. New York: W. W. Norton.

Jung, C. G. (1984/2001). 정신요법의 기본문제. 한국융연구원 융 저작 번역위원회.

Jung, C. G. (1984/2001). C. G. Jung: Grundfragen zur praxis. Translation Committee of the C. G. Jung Institute of Korea.

Marcia, J, E. (1976). Identity six years after: A follow-up study. Journal of Youth and Adolescence, 5, $145-160$.

Reed-Danahy, D. (1997). Auto/ethnography: Rewriting the Self and the Social. Oxford and New York: Routlege.

Schore, A. N. (2014). Attachment, neuroscience and sandplay therapy. Source book 2014 International Conference of the Korean Society of Sandplay Therapy.

Secord, P. F., \& Backman, C. W. (1964). Social psychology. New York: McGraw-Hill.

Skovholt, T. M. (2001). The resilient practitioner: Burnout prevention and self-care strategies for counselors, therapists, teachers, and health professionals. Boston, MA: Allyn \& Bacon.

Ministry of Education, Science and Technology (2021). The status of placement of professional counselors nationwide. Materials provided to the 2021 National Audit.

Ministry of Education, Science and Technology (2009). Working Manual for Professional teacher-counselors. 김근화 (2013). 학업소진과 부모성취압력의 관계에서 학업 통제감의 역할에 대한 종단연구:

잠재성장모형을 활용하여. 고려대학교 대학원 교육학과 석사학위논문.

김명찬 (2013). 질적 글쓰기2-Methods. 피어슨 아카데미 프레스.

김명찬 (2015). “상처 입은 아버지와 아들”의 회복에 대한 자문화기술지. 한국교육인류학회.

교육인류학연구, 18(4), 85-120.

김인규 (2012). 학교상담 발전방안 연구. 전라북도교육청.

김인규, 조남정 (2011). DACUM법을 활용한 전문상담교사 직무분석 연구. 한국교원연구, 27(2), 97-115.

김정숙, 유금란 (2010). 전문상담교사의 역할갈등과 소진의 관계에서 전문직 정체성의 조절

효과. 한국심리학회지: 상담 및 심리치료, 22(1), 53-69.

김지연, 김동일 (2015). 전문상담교사의 직업적응 과정연구. 상담학연구, 16(1), 73-93. 
Journal of Symbols \& Sandplay Therapy, Vol.12 No.2.

김지정, 이영순 (2014). 전문상담교사의 적응과정. 한국심리학회지: 상담과 심리치료, 26(2), 223-246.

박근영, 임은미 (2014). 전문상담교사의 소진경험에 대한 개념도 연구. 중등교육연구, 62(1), 171-198.

박은영, 김명찬 (2018). 관계적 표상으로서 기억의 형성과 변환과정에 관한 협력적 자문화기 술지. 질적탐구, 4(2), 97-129.

박순용, 장희원, 조민아 (2010). 자문화기술지 방법론적 특징을 통해 본 교육인류학적 가치 의 탐색. 교육인류학연구, 13(2), 55-79.

송미라, 한기백 (2015). 과학고생이 지각한 부모양육태도와 주관적 안녕감의 관계: 학업적 자기효능감과 또래관계의 매개효과. 청소년학연구, 22(4), 93-111.

이명랑 (2018). 일-가정 갈등, 가정-일 갈등이 전문상담교사의 소진에 미치는 영향: 인지유연 성과 스트레스 대처방식 중심으로. 고려대학교 교육대학원 석사학위논문.

이자영, 남숙경, 박희락, 김동현, 이미경, 이상민 (2008). 진로의사결정 유형과 진로성숙도 간

의 관계에 대한 진로결정 자기효능감의 역할. 한국교육학연구, 14(1), 205-223.

이지원, 오인수 (2016). 전문상담교사의 전문성 발달 경험에 관한 현상학적 연구. 상담학연구,

17(4), 351-372.

이상민, 안성희 (2003) 학교상담자는 무엇을 해야 하는가?. 상담학연구, 4(2), 281-293.

이현아, 이기학 (2009). 전문상담교사의 직무스트레스 요인과 직무만족도, 심리적 소진의 관

계. 한국심리학회지: 학교, 6(1), 83-102.

이현진, 김명찬 (2017). 복합외상 경험자의 자녀양육 경험에 대한 자문화기술지. 질적탐구, 3(2), 329-353.

Jang, M. (2017). Analytical psychological sandplay therapy. Seoul: Hakji-sa.

Jang, M. (2017). Play therapy. Seoul: Changji-sa.

정환경 (2015). 전문상담교사의 역량 척도 개발 및 타당화. 경성대학교 대학원 박사학위논

문.

진혜은 (2014). 전문상담교사의 감정노동에 관한 질적연구. 우석대학교 석사학위 논문.

채현순, 장유진 (2016). 전문상담교사의 전문직 정체성 형성 과정에 관한 질적 연구. 전문상

담교사의 전문직 정체성 형성 과정에 관한 질적 연구. 한국교원교육연구, 33(4), 167-192. 최두호 (2012). 학교 성취압력의 학업성취에 대한 영향: 사회경제적 배경에 따른 차별적 효 과를 중심으로. 고려대학교 대학원 교육학과 석사학위논문.

최재진 (2010). 전문직적 특성의 교원 보수체계 반영에 대한 초중등 교원의 인식 연구. 한국 교원대학교 대학원. 박사학위논문.

한국교육개발원 (2011). 상담사 자격제도 개선 방안 연구: 학교상담을 중심으로. CR2011-36. 
한아름, 오인수 (2014). 학교상담자의 직무스트레스와 심리적 소진의 관계에서 정서지능의 조절효과. 교원교육, 30(2), 227-251.

Burnham, J. J., \& Jackson, C. M. (2000). School counselor roles: Discrepancies between practice and existing models. Professional School Counseling, 4(1), 41-49.

Chang, H. (2008). Autoethnography as method. Walnut Creek, CA: Left Coast Press, Inc.

Chang, H., Ngunjiri, F. W., \& Hernandez, K. C. (2013). Collaborative

autoethnography. Walnut Creek, CA: Left Coast Press, Inc.

Ellis, C. (207). Telling secrets, revealing lives: Relational ethics in research with intimate others. Qualitative Inquiry, 13(1), 3-29.

Erikson, E. (1994). Identity and the life cycle. New York: W.W.Norton.

Jung, C. G. (1984/2001). 정신요법의 기본문제. 한국융연구원 융 저작 번역위원회.

Marcia, J, E. (1976). Identity six years after: A follow-up study. Journal of Youth and Adolescence, 5,145-160.

Reed-Danahy, D. (1997). Auto/ethnography: Rewriting the Self and the Social. Oxford and New York: Routlege.

Schore, A. N. (2014). 애착, 신경과학과 모래놀이치료. 한국임상모래놀이치료학회 2014 국제학 술대회 자료집.

Secord, P. F., \& Backman, C. W. (1964). Social psychology. New York: McGraw-Hill.

Skovholt, T. M. (2001). The resilient practitioner: Burnout prevention and self-care strategies for counselors, therapists, teachers, and health professionals. Boston, MA: Allyn \& Bacon. 
상징과모래놀이치료, 제 12 권 제 2 호

Journal of Symbols \& Sandplay Therapy

2021, 12, Vol. 12, No. 2, 145-169.

doi https://doi.org/10.12964/jsst.21010

\section{'사이'에서 고민하는 학교상담자(전문상담교사와 전문상담사)의 개성화를 위한 자기성장 스토리에 대한 자문화기술지 - 모래놀이치료와 꿈분석 집단에서의 성찰을 중심으로 -}

Auto-ethnography of Self-growth Stories for the Individuation of School Counselors (Professional Teacher-counselors and Professional counselors)

Who Are Suffering from 'between'

- Based on Insight in Sandplay Therapy and Dream analysis -

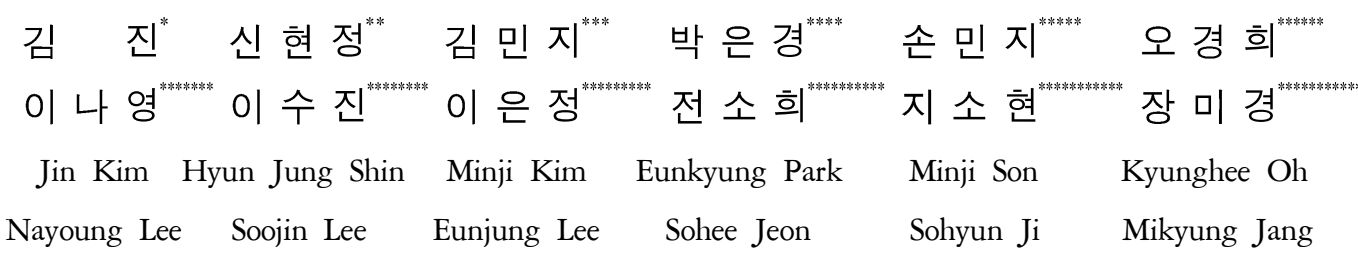

\section{$<$ Abstract $>$}

This article aims to provide auto-ethnography for self-growth and individuation through the

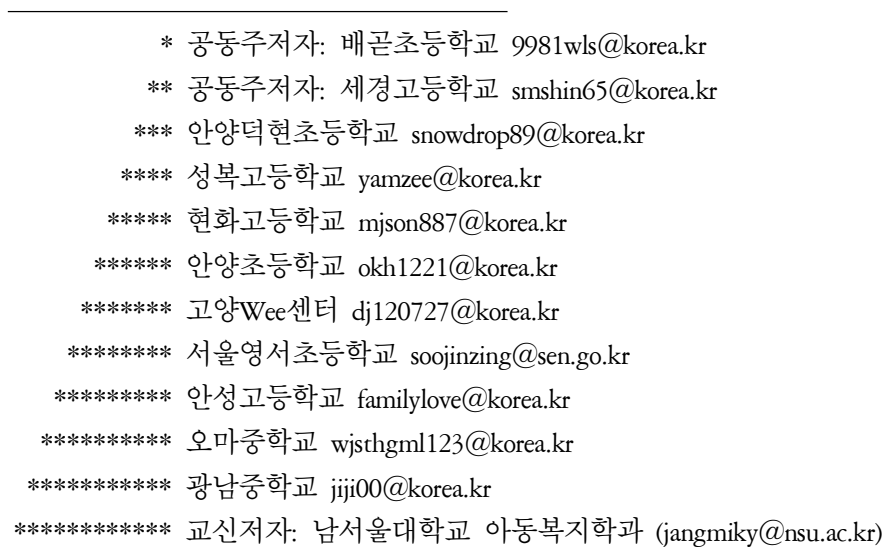


Journal of Symbols \& Sandplay Therapy, Vol.12 No.2.

experience of applying sandplay therapy to school counseling of 11 professional teacher-counselors and professional school counselors, changes in the counseling effect, and the counselors' own sandplay therapy and dream symbol analysis. The auto-ethnographical research has mainly been about the experiences of one or two researcher(s)-participant(s), but in this study, 11 researchers-participants participated in the study to express and inform their common experiences in school counseling. The researcher-participants have experience of school counseling from 2 years and 5 months to 11 years and 5 months, and they are all female counselors. Research data include dreams and dream associations, sandplay pictures and association about sandplay pictures, related life events and experiences, contemplation, recollection, insights, observations of researchers/research participants, sharings by group SNS, individual interviews have been used. The four common themes are found: 1. dreaming of becoming school teacher-counselor/school counselor, 2. frustration: self-blame and resentment, 3. searching for breakthrough: finding identity, 4. accepting incompleteness, which is still in progress. Among them, searching for breakthrough: finding identity has two sub-themes: sandplay and dream: encounter with the inner world and wrestling with regrets for children.

Keywords : professional school teacher-counselor, professional school counselor, individuation, growth, sandplay therapy, dream symbol analysis, auto-ethnography 


\section{I. 서 론}

우리는 학교상담자로(전문상담교사, 전문상담사)로 학교 현장에서 아이들을 만나 그들의 어려움을 덜어주고자 고군분투의 시간을 보내고 있다. 이 일을 향한 우리의 노력은 학부 과정에서부터 시작되었다. 상담 관련 학과에 입학한 뒤에도 경쟁을 통해 교직 이수를 하거 나 교육대학원에 진학하여 수학하며 많은 시간과 비용을 투자하였다. 그리고 이어진 교사 임용시험에 합격하기 위해 '고시'라고 할 만큼 힘든 과정을 통과하였다. 또한 어떤 이는 전 문상담사가 되기 위해 상담 관련 자격취득을 위해 수 년의 시간을 보냈다. 이런 힘들고 어 려운 과정을 통해 우리는 '전문상담교사' 그리고 '전문상담사'가 되었다. 그렇기 때문에 학교 현장에서 학생들의 성장을 돕겠다는 사명감과 자부심으로 무장된 '상담자'가 되었다.

그러나 시간이 지나면서 우리는 여러 가지 '사이'에서 많은 것을 고민하고 힘들어하고 있 는 자신을 발견했다. 과연 '나는 교사인가 상담자인가?', '내가 만나는 학생들은 내담자인가 학생인가', '과연 나는 진정한 상담을 하고 있나?’라는 질문에 휩싸이게 되었다. 우리는 특별 실(상담실)에 단독 상주하며 여러 심리 - 정서적인 어려움을 호소하며 수시로 상담실을 방문 하는 아이들을 만나고, 가끔은 하루 종일 엄마처럼 돌봐주기를 바라는 학생들을 마주한다. 그러기를 반복하며 상담학에서 배운 상담 세션의 구조화는 쉽지 않았고, 문제가 무엇인지 고심하기도 하고, 그 원인이 상담자 전문성의 부족에 있는 것은 아닌지 자책했다.

우리는 '내담 학생의 니즈(needs), 동료 교사의 니즈(needs), 그리고 상담교사의 역할 사이' 에서 자주 혼란스러웠다. 담임 및 교과 교사들은 교실에서 감당하기 어려운 학생들을 상담 실로 보내며 마법처럼 학생의 문제를 해결해주리라는 기대를 뿜어냈고, 이는 학교 내 구성 원들의 서로 다른, 때로는 상반된 기대를 충족시켜야 한다는 압박감으로 다가왔다. 또한 내 담 학생 가족의 적극적인 도움 없이 상담하는 것은 매우 고달팠고, 풍부한 정보를 수집하 지 못한 채 인테이크(intake) 한 '학생'에게 안타까움을 느껴야 했다. 그 부분에서도 우리는 여전히 그것이 '상담자'로서의 우리의 능력 부족에서 기인하는 것은 아닌지 자책했다.

교과 교사 및 학교 관리자(교장·교감) 관계 사이에서도 우리는 고뇌해야 했다. 상담의 비밀보장을 직업윤리의 핵심으로 생각하는 우리가 그들에게 내담자와 관련된 상담내용을 공유하는 것은 제한된다. 그리고 학교에 한 명씩 배치되는 전문상담교사 혹은 전문상담사 는 학생 전체를 대상으로 상담 업무를 기획- 운영해야 한다. 이로 인해 학교내 유일하고 고유한 업무를 가진 한 명의 상담자로서 때로는 혼자라는 소외감을 느끼며 주변인(marginal person)으로서 소속감의 부족을 겪기도 했다. 이러한 혼란 역시 상담자로서 전문성의 부족에 서 기인한다고 생각하며, 이를 상담 관련 학회 수련, 연구회 가입, 대학원 진학 등 우리가 상담자로서의 전문성을 향상함으로써 해결할 수 있는 부분이라고 믿었다.

이렇게 진실한 전문상담교사 또는 전문상담사가 되고자 노력하는 과정에서 우리는 '나의 
Journal of Symbols \& Sandplay Therapy, Vol.12 No.2.

가정은 어쩌지?'하는 걱정과 미안한 마음에 시달려야 했다. 내가 학교 현장에서 유능한 전 문상담교사 또는 전문상담사가 되기 위해 노력하는 만큼 가정과 가족에게도 잘해야 한다고 생각했다. 두 가지 모두를 균형 있게 잘 해내지 못할 때는 우리 자신에 대해 자책했고 죄 책감을 어쩌지 못했다.

그래서 우리는 우리 자신과 삶을 알아가는 과정을 시작했다. 시작할 수밖에 없는 내면의 ‘압력' 같은 것을 느꼈다. 그러지 않으면 '사이'에서 스스로 파괴될 것 같은 '두려움'을 느꼈 다. 우리는 우리 자신을 알아가는 과정에서 정책, 제도 등의 환경적 문제와 사회의 성취, 성공제일주의 영향을 받은 우리의 문제가 혼재해 있다는 것을 깨달았다. 무엇보다 교사로 서의 나(아이러니하게도 상담자로서가 아니라 그러면서 동시에 상담도 성공적으로 하려고 하는 교사로서), 가정에서의 나를 인정받는 것이 중요했기 때문에 자신이 속한 집단 모두에 기여하고 있다는 피드백을 듣기 바랐다. 이러한 바람이 현실적으로는 그럴 수 없다는 것을 인지하면서도 감정적으로 미흡하거나 실수하는 것을 받아들이지 못했다. 그러나 누구나 알 수 있듯이 완벽하고 완전해지는 것은 불가능한 것이지만, 그런데 우리는 그것이 불가능한 것임을 처음에는 알지 못했다. 우리나라 학생들은 사회와 부모의 과도한 성취압력으로 인 해 사교육에 시달리며, 학업적 소진을 경험하듯이(최두호, 2012; 김근화, 2013; 송미라, 한기 백, 2015) 그들은 마주하는 우리들 또한 수월성 논리 안에서 애쓰며 심리적, 신체적으로 점 점 지쳐갔던 것이다. 학생들의 정서적 안정, 성장, 발달 등을 조력하는 것이 때로는 그들에 게 더 이상 도움이 되지 않거나 우리 자신에게도 도움이 되지 않는 '소진(burn-out)'을 경험 하였다(Skovholt, 2001).

이 과정에서 우리를 이끌고 간 내면의 질문은 '우리는 왜 더 유능해져야 한다고 강박적 으로 생각해야 했을까?였다. 이러한 고민을 가지고 우리는 우리 자신이 어떤 사람인지, 학 교상담 전문가로서 '나'라는 정체성은 무엇인지를 찾기 위해 모였다. 사실 처음에는 자기 자신을 알아가는 공부 역시 상담교사 또는 상담자로서 전문성을 키우는 방법이라고만 막연 히 생각하고 여기저기 뛰어다녔다. 그러다 우리는 자신을 알기 위해 자신의 성장을 위한 꿈분석과 모래놀이치료 집단에 참여하게 되었다. 거기서 우리는 지금까지 우리의 애쓰고 수고함이 일-가정-여가의 균형감각을 가진 그리고 자신의 욕구가 어떻게 일과 삶에 투사되 는지를 아는 '성숙한 나'를 찾기 위한 과정임을 알았다. 우리는 각자의 꿈을 이야기하고 꿈 장면 중에서 인상적인 부분을 피겨를 활용해 모래상자에 만들었다. 그리고 떠오르는 연상 들을 이야기했다.

우리는 그 과정에서 우리의 자부심, 고민, 갈등, 죄책감, 정체성 혼란 등 여러 가지 경험 속에서 느껴지는 생각과 감정을 이야기했다. 그리고 어린 시절 가정과 학교에서 배운 것에 대해 이야기하기 시작했다. 우리가 교육받은 꿈은 유능해지는 것, 모든 것을 잘 해내는 것, 인정받는 것, 부족함을 보여주지 않는 것, 무능함과 부족함으로 인한 죄책감을 느끼지 않는 
것들이었다. 그리고 또 한 가지는 우리의 의지와 이성적이고 합리적인 노력으로 이런 것들 을 성취할 수 있다는 착각을 하고 있다는 것이었다. 이것은 교사로서는 유용한 것들일 수 있을 것이다. 그러나 상담은 우리의 이성적이고 합리적인 의지와 노력만으로는 가능하지 않은 것이다. 우리는 일과 우리 자신의 삶을 함께하는 법, 쉬는 법, 우리 자신과 타인의 감 정을 존중하는 법, 실수하는 삶을 사는 법, 자신의 열등한 부분을 살아내는 법은 배우지 못 했다. 열등한 부분은 감추거나 극복해야 하는 것으로 배웠다. 그런데 우리는 학교에 잘 적 응하지 못하는 학생들, 공부에 관심 없고 잘하지 못하는 학생들, 자신의 감정을 존중받지 못한 학생들, 열등하고 인정받지 못한다고 생각하는 학생들, 감정을 조절하지 못하거나 억 압하고 살아온 학생, 사람들에게 사랑받지 못한 학생들을 만난다. 교사인지 상담자인지 구 분하지 못한 채 학생 또는 내담자를 학교와 사회에 잘 적응시키겠다는 교사의 정체성만을 가지고 아이를 만나게 되는 경우도 있었다. 하지만 우리는 상담 과정에서 학생들이 또는 내담자들이 멋지고 훌륭하게 변화하고 자신의 잠재력을 발휘하는 모습도 여러 차례 목격하 였다. 특히 상담 과정에서 이성, 생각 보다는 내면의 감정과 상징을 사용하는 모래놀이치료 를 통해 우리가 모르거나 무시했던 내담자들의 잠재력과 발전 가능성을 더 많이 발견하게 되었고, 회기가 진행되면서 자기를 인식하고, 긍정적으로 변해가는 모래 장면을 보면서 그 가능성을 객관적으로 보게 되었다. 직접 모래상자를 만들고, 사례 슈퍼비전을 받으면서 모 래놀이가 가진 치료적 힘을 자연스럽게 느낄 수 있었다. 상담자로서의 나의 성장과 내담학 생의 성장이 함께 가는 것을 경험한 것이다.

학교상담자들의 역할 혼란은 정책적, 현실적 어려움에서도 기인한다. 전문상담교사는 전 문, 상담, 교사라는 세 단어가 합쳐진 말로, 사전적 정의의 전문직은 전문적인 지식이나 기 술이 필요한 직업(표준국어대사전)을 일컬으며, 특정 면허증 및 자격증 소지자를 묶어서 전 문직이라고 한다. 전문직은 깊은 수준의 전문화된 지식, 사명감과 윤리의식, 자율성과 책임, 지속적인 전문능력의 개발 등의 조건을 갖추어야 하는 직업을 일컫는다(최재진, 2010). 이러 한 점에서 교사와 상담자는 전문직에 해당하며 교사와 상담자는 학생의 내적인 성장 과정 을 조력한다는 점에서 같지만, 교사는 교육을 통해 목적지향적인 가치와 변화를 실현하고 자 학생의 성장을 이끄는 주체가 되고, 상담자는 상담을 통해 내담자가 스스로 삶의 주체 가 되도록 조력한다는 점에서 다르다.

전문상담교사는 학교상담자 중 전문상담교사 1 급 또는 2 급 자격증을 소지한 자로서 시 · 도 교육청 위(Wee)센터 및 위(Wee)스쿨과 초·중·고등학교 위(Wee)클래스에 임용·배치되 어 학교상담 및 관련 업무를 전담하는 교사를 말한다. 2021년 현재 전국 전국에 3,785 명의 전문상담교사가 배치되어 있다. 교육과학기술부가 2009년 '전문상담교사 운영 및 활동 매뉴 얼에 제시한 전문상담교사 역할모형의 세 가지 특성은 a. 예방적 서비스와 반응적 서비스 의 결합 모형, b. 목표 중심 학교상담모형, c. 조력자로 모형이 있다. 그러나 역할수행 갈등 
Journal of Symbols \& Sandplay Therapy, Vol.12 No.2.

은 이상적인 상담모형과 학교 현실 사이에서 발생할 수 있으며(Burnham \& Jackson, 2000) 당 연하게도 역할수행은 주관적 역할기대와 외부의 타인에게서 받는 객관적 역할기대로부터 영향을 받는다(김정숙, 유금란, 2010; Secord \& Backman, 1964).

상담교사는 상담자로서의 역할 뿐 아니라 학교라는 특수한 공간이 요구하는 다양한 역할 을 해야 한다. 학교상담자는 상담 뿐 아니라 때로는 행정업무, 학생지도, 사회복지사 역할 을 해야 한다. 이러한 특수한 상황은 관리자, 동료교사, 학부모의 학교상담에 관한 인식 부 족으로 학교상담자들로 하여금 낮은 자존감을 경험하게 하고 일반교사들의 협조 없이는 학 생들의 상담 관련 업무를 하는 데 어려움을 겪으면서 더 많은 소모적 감정노동에 이르게 하고 있다.

전문상담교사의 전문직 정체성 형성과정에 관한 한 질적 연구(채현순, 장유진, 2016)에서 는 전문상담교사의 전문직 정체성 형성과정의 중심 현상은 '전문상담교사로서 나의 존재를 물음'인 것으로 나타났다. 이 연구에서는 시간의 흐름에 따라 범주 간의 관련성을 연결시키 는 과정의 분석 결과, 참여자들은 열정과 무지, 혼돈과 갈등, 의문과 고민, 실천적 고투 그 리고 개별적 정체성 구성과 같은 다섯 단계를 거치며 정체성을 형성해 가는 것으로 분석되 었다. 전문상담교사들은 상담에 대한 전문성 부족 자각, 직무환경의 어려움, 소수자로서 다 수의 교과교사들과의 소통의 어려움과 정서적 고립, 상담의 특수성과 전문성을 이해받지 못함, 학생들에게 존재의 의미를 고민, 흔들리는 정체성 등의 어려움으로 '전문상담교사로 서 나의 존재를 물음'이라는 의문을 스스로 던졌다. 이에 대해 전문상담교사들은 '정서적 지지와 지원을 받음, '학교상담에 대한 열정을 품음', '상담과 전문상담교사에 대한 주변의 인식 변화를 경험함 같은 중재 조건과 '지식과 경험의 통합으로 전문성을 함양함, '안정된 학교상담 시스템을 만들어감, '현장의 요구를 반영한 제반 제도 및 정책의 변화를 추구함, '개인적 차원에서의 적응을 모색함 같은 다양한 대처방식을 통해 공통된 과정을 거친다는 것을 알 수 있다. 이들은 '전문상담교사임에 만족을 느끼고, 학교상담 전문가로서의 정체성 이 형성되며, 좌절과 소진을 견디고 버텨내었다. 그러나 이 연구 결과에 의하면, 전문상담 교사들은 여전히 좌절과 소진을 견뎌야 하는 상황에 있다고 할 수 있다.

전문상담교사들이 가정과 일, 일과 가정 사이에서도 역할 갈등을 겪는다는 연구도 있다 (이명랑, 2018). 김정숙과 유금란(2010)의 연구에서는 역할갈등이 무능감과 유의미한 관계가 있었으며 전문직 정체성과 소진(신체적 피로감, 무능감, 비협조적 업무환경, 내담자에 대한 가치 저하, 사생활 악화) 사이에도 유의미한 부적 상관관계가 있었다. 역할 갈등과 소진(신 체적 피로감, 비협조적인 업무환경)의 관계에서 역할 갈등이 높더라도 전문직 정체성이 높 으면 소진을 덜 경험하였다.

꿈이 상담이나 분석 또는 심리치료에서 갖는 치유적 기능에 관해 여러 가지 이론이 있지 만 분석심리학적 관점에서 꿈은 인격발달의 전체성을 추구하는, 꿈꾼 이의 정신의 중요한 
관심사를 드러내는 무의식으로부터 나오는 의미와 이미지라고 할 수 있다. 분석심리학적 측면에서 인격 발달의 전체성을 지속적으로 무시하게 되면 개인은 심리적 (때로는 신체화 증상을 포함하여) 증상이나 갈등을 갖게 되는데 이때의 증상이나 갈등은 인격의 전체성을 이루라는 무의식의 신호라고 할 수 있다. 무의식은 의식이 사용하는 언어적 의사소통 방식 이 아닌 이미지 즉 상징을 통해 소통한다. 따라서 무의식의 신호를 이해하기 위해서는 상 징의 의미를 이해하는 것이 중요하다. 꿈은 무의식이 이미지를 보내는 방식 중 대표적인 것이다. 따라서 꿈에 대한 분석은 실용적이고 치유적인 기능을 갖는다(Jung, 1984/2001). 개 인 삶의 과거, 현재, 미래와 관련된 꿈의 특성은 연대기적 회상 또는 연상을 불러일으킨다 (Jung, 1984/2001).

우리는 꿈에 대한 연상을 이야기하는 과정에서 자기 성찰 또는 통찰이 일어난다는 것을 우리는 알게 되었다. 즉 우리의 이성이 알지 못한 채 우리를 시달리게 만드는 각자의 내면 에 있는 욕구를 알게 했고 그것을 해결하게 하는 무의식적 자원들을 깨닫게 된 것이다. 꿈 은 이성적이고 의식적인 방어가 약해진 가운데 자신을 나타나게 하기 때문이다. 꿈은 때로 는 현실의 삶 속에서 내가 하지 못하는 말과 행동을 하게 하기도 하며 과거에 해결되지 못 했던 마음속 과제들이 현실의 삶의 모습으로 다시 재현되게 하기도 하고 내 안에 내재되어 있던 이중적 또는 의식하지 못한 옥구나 특징들을 나타나게 한다. 꿈 장면을 모래상자에 재연하면서 미처 인식하지 못했던 부분에 대한 의미를 이해하게 되는 경우가 많이 있었다. 그 과정에서 자신의 모습이 현재의 삶에서 어떠한 의미를 주는지를 알게 될 뿐만 아니라 통합적이고 진정한 나 자신이 되기 위해서 앞으로 내가 취해야 할 태도를 깨달을 수 있게 해준다.

꿈과 유사하지만 깨어있는 상태에서 무의식의 상징투사 작업 중 하나가 모래놀이치료이 다(장미경, 2017). 눈으로 보이는 작업이지만 내면세계에 관한 작업인 것이다. 설사 모래상 자에 외적 사건이 표현되었다 하더라도 그것은 발생한 사건 자체가 아니라 그것을 표현한 사람에게 의미를 갖는 것으로서의 사건이다. 모래상자에서의 작업과 언어적 표현을 통해 그 사건의 영향으로부터 받은 것이 무엇이고 영향을 일으킨 개인적, 내적, 정신적 내용이 무엇인지 깨닫게 되며 개인적, 내적 정신적 내용이 어떻게 사건에 투사되어 영향을 받게 되는지를 이해하게 된다. 또한 꿈작업에서처럼 모래놀이치료에서도 의식과 무의식의 관계 가 중요하다. 모래놀이치료 작업을 하는 이유가 바로 무의식을 의식에 통합시켜 의식의 범 위를 확장하고 자아를 새롭게 하여 인격 발달의 전체성을 이루고자 하는 것이기 때문이다. 무의식을 의식화하기 위해 상징을 활용하고 있으며 모래, 모래상자, 피겨 등이 상징으로써 그 역할을 한다(장미경, 2017).

우리는 꿈작업과 모래놀이치료를 직접 경험하면서 자신의 무의식을 만나게 되었고, 놀라 움, 신기함, 경이로움, 불편함 등의 복합적 감정을 경험하였다. 이러한 경험은 자신을 스스 
Journal of Symbols \& Sandplay Therapy, Vol.12 No.2.

로 직면하게 하였으며 앞날에 대한 삶의 방향에까지 영향을 미쳤다. 궁극적으로는 이 과정 에서 우리 자신의 개인적 이슈들이 우리의 삶을 어떻게 지배해 왔으며 외부의 현실적, 제 도적 요인들과 그것이 어떻게 얽혀있는지 그리고 그 과정에서 우리는 어떤 입장과 태도로 임해야 하는지를 알게 되었다. 가장 중요한 것은 자신의 치료적 경험을 통해 내담 학생들 을 더 깊이 공감하고 이해할 수 있게 되었다는 것이다.

자신의 처지와 입장을 이해하고 함께 느끼는 사람과의 대화는 마음의 위로를 주며 나와 같은 사람이 있다는 것은 힘이 된다. 그런 의미에서 동료상담교사와의 대화는 감정을 정리 하는 데 많은 도움이 된다(진혜은, 2014). 각자의 이야기를 공감하며 우리는 서로 너무 비슷 한 경험을 해왔으며 유사한 삶을 살고 있다는 것을 알게 되었다. 그 과정에서 우리는 우리 의 경험과 이야기를 세상에 알리고 싶다는 생각에 이르게 되었고 이야기를 붙여 나가는 릴 레이 글쓰기를 하기로 이구동성 동의하였다.

\section{II. 연구방법}

\section{1. 자문화기술지}

본 연구의 연구자들은 연구 참여자이자 연구자로서 복수의 개인의 경험을 제시할 수 있 는 방법을 찾고자 했으며 그 결과로 선택한 방법이 자문화기술지이다. 자문화기술지는 질 적 연구 방법 중 하나로 자전적으로 연구자의 경험을 이야기로 구성하고 사회, 정치, 문화 적으로 연결 지어 해석하며, 자기(self)와 타인(others)간의 공유된 문화적 자기(self)의 경험을 중심으로 기술하는 방식이다(Chang, 2008). 즉 자문화기술지는 자신과 타인이 공유하고 있는 문화적 맥락을 자신의 이야기 중심으로 풀어나감으로써(이현진, 김명찬, 2017) 연구 결과로 서 밝혀진 내용의 타당성을 확보하고자 한다. 그러한 측면에서 본 연구의 연구자들 각 개 인의 이야기는 함께 경험하는 학교상담의 문화적 맥락에서 나누어지는 이야기이다.

자문화기술지 방식으로 쓰인 논문들은 대체로 연구자이자 연구 참여자 1 인의 글이다. 자 문화기술지는 저자 자신이 체험한 과거의 경험이나 사건들을 시간 순서에 따라 일정한 형 식으로 이야기하는 것을 말하며 고도로 감상적이고 사적인 글쓰기 방식을 활용하면서도 개 인의 삶을 이론적으로 이해하려는 접근(김영천, 2013)이기 때문에 본 연구에서 적용한 자문 화기술지 접근이 적절한 것인가에 대한 고민과 토론을 했다. 그 후 잠정적으로 이른 결론 은 질적 논문의 타당성 및 객관성 확보가 상호주관성에 의해 이루어진다는 점을 고려할 때 복수의 개인들의 개별적 경험과 더불어 공통의 성찰적 자문화기술지가 가능할 것이라는 가 정 하에 자문화기술지 연구접근이 적절하다는 결론에 이르게 되었다. 김영천은 $\mathrm{De}$ 
Munck(2000)을 인용하여, 포스트모더니즘의 관점에서 인간은 취약함의 극복을 위해 상호의 존적일 수밖에 없으며 타인을 의지함으로써 자기를 구성한다고 하였다(김영천, 2013, 박은 영, 김명찬, 2018). 이렇게 형성된 개인의 주관적 경험과 인식은 집단경험을 반영할 수밖에 없다. 이러한 특성으로 인해 여러 명으로 구성된 연구자/연구 참여자들의 ‘우리’라는 공통경 험이 가능하며 자문화기술지는 우리들의 경험이 어떻게 개인적이면서 동시에 ‘우리’의 공통 경험인지를 보여줄 수 있는 적합한 연구 방법이라고 할 수 있을 것이다. 언급한 바와 같이, 자문화기술지 방식은 연구자 개인이 자신의 자전적 내러티브(autobiographic narratives)를 통해 자신이 경험하고 살았던 사회적이고 문화적인 맥락에서 자기(self)와 타인(others)이 공유하고 있는 경험을 밝혀내고자 하기 때문이다(박순용, 장희원, 조민아, 2010).

그럼에도 불구하고 자문화기술지 접근은 여전히 연구의 타당성 내지 객관성에 대한 질문 을 제기한다. 박은영과 김명찬(2018)은 관련 학자들을 인용하면서 자문화기술지의 자료출처 가 자아의 사용이기 때문에 연구가 지나치게 자기 자신에게 관대하며 자기탐닉적이라는 비 판을 받아 왔다고 했다. 대부분의 질적 연구가 그러하듯이 자문화기술지 방식 또한 연구자 의 주관성(subjectivity)을 통한 연구자와 연구 참여자가 공통으로 지각하고 느끼는 상호주관 성(intersubjectivity)을 연구의 객관성 내지 타당성으로 제시한다(박은영, 김명찬, 2018). 상호주 관성은 신경학적으로도 근거가 있는 개념으로서, Schore(2014)는 상호작용하는 두 사람의 우 뇌 사이의 상호작용에 의에 신체적, 암묵적, 무의식적으로 알게 되는 서로의 상태라고 상호 주관성을 정의하였다. 분석심리학에서의 직관(intuition), 대상관계심리치료의 투사적 동일시 (projective identification)와도 부분적으로 유사한 개념인 상호주관성은 모래놀이치료에서도 중 요하게 언급되는 개념이다(장미경, 2017). 내담자가 의식하지 못하거나 언어로 표현하지는 않았지만 모래상자에서 치료자와 내담자가 상상한 것이 내담자의 무의식에 대해 많은 단서 를 줄 수 있다(장미경, 2017). 모래상자라는 제 3 의 공간이 내담자와 치료자 사이에 태도, 감 정, 신념 등 복합적 에너지를 흐르게 하며, 이러한 공통의 공간에서 공통으로 느끼고 지각 하는 지점이 나타날 수 있다.

상호주관성은 말 그대로 주관적으로 느껴지는 것을 통해 상대를 객관적으로 이해한다는 의미이다. 그렇기에 상담 관계에서의 상호주관성은 우리가 차용할 자문화기술지 연구 방법 의 타당성에 대한 근거로 사용될 뿐 아니라 모래놀이치료 그 자체의 특징으로 이해될 수 있는 것이다. 비언어적 개입을 강조하는 모래놀이치료에서 연구 참여자들은 서로가 작업한 모래상자를 통해 자신의 이야기를 나누고 거기서 파생되는 감정 그리고 상상, 연상 등을 민감하게 알아차리고 함께 나누면서 서로 간의 상호주관성을 이해하는 경험을 하였다.

본 연구는 집단이라는 측면에서 상호주관성을 언급할 수 있다. 연구자/연구 참여자가 복 수이기 때문에 서로의 공감대를 통해 상호주관성을 증명해주는 특성을 갖고 있다고 할 수 있다. 각자 개인의 경험이면서 동시에 우리의 경험이라는 것을 보여주었다. 한 명의 개인 
Journal of Symbols \& Sandplay Therapy, Vol.12 No.2.

연구자/연구 참여자로 이루어진 자문화기술지의 경우 독자가 공감해야 하는 상호주관성의 측면이 있지만 본 연구는 각자의 경험을 나누고 토의하는 과정에서 자연스럽게 상호주관성 이 존재함을 체험했다.

자문화기술지의 유형은 크게 세 가지로 구분된다(Reed-Danahay, 1997). 첫 번째는 연구자 의 성찰이 강조되는 성찰적 문화기술지(reflective ethnography), 두 번째는 외국인, 여성, 장애 인 등의 사회 소수자의 관점에서 기록된 소수자 문화기술지(minority ethnography), 그리고 마지막 세 번째는 한 개인의 경험을 사회문화적 맥락에서 분석하는 자전적 문화기술지 (auto-biographic ethnography) 등이다. 우리의 이야기는 연구자이자 연구 참여자로서 심리, 사 회적 맥락에서 우리의 성찰적 경험을 분석한다는 측면에서 성찰적 문화기술지에 더 가깝다 고 할 수 있다. 본 연구를 다수의 일반교사들 사이에 있는 소수자로서의 상담교사의 관점 에서 소수자 자문화기술지 접근으로 기술할 수도 있겠지만 상담교사로서의 자신과 사회, 문화적 맥락에서 경험을 성찰적으로 기술하기 위해서는 성찰적 자문화기술지 방법이 더 타 당할 것으로 판단되었다. 이러한 맥락은 자문화기술지가 삶과 인간 그리고 사회/문화에 대 한 이해를 높이며, 자문화기술지의 주된 목표는 아니지만(김영천, 2013) 개인의 삶과 사회/ 문화를 이해하는 과정을 통해 개인의 영향과 사회/문화적 영향을 이해하게 됨으로써 자신 과 타인에 대한 조망을 넓히고 이는 치유적 효과를 가져올 것으로 판단된다. 자문화기술지 를 활용하여 연구 참여자로 하여금 자신들의 이야기를 하고 문화적 분석을 하도록 하여 자 신들의 자기(self)에 대해 깨닫도록 하는 것은 상담자로서의 자기 인식을 확장시키고 전문가 로서의 역량 강화에 도움이 될 것이다. 본 연구에서도 연구자/연구 참여자들인 우리는 자기 분석과 이해를 위한 집단 경험 뿐 아니라 논문을 작성하는 과정에서 우리의 경험과 삶을 돌아보고 그것을 타인, 사회/문화적 맥락에서 돌아보는 과정이 더욱 활발히 이루어졌고 그 과정에서 더 깊은 통찰과 넓은 조망을 갖게 되었다는 것 그리고 이것이 치유기능을 가져왔 다고 할 수 있다.

\section{2. 연구 참여자}

연구 참여자들은 서울 및 경기도교육청 소속 전문상담교사 9 명과 전문상담사 2 명이다. 연구 참여자들은 Wee센터, 초등학교, 중학교, 고등학교에 소속되어 있으며 모래놀이치료 워 크샵 및 꿈분석 집단을 리드한 교수 1 인이 공동연구자로 참여하였다. 연구 참여자들의 인 적사항을 정리하면 표 1 과 같다. 인적사항 중 상담 관련 자격은 모래놀이상담사와 국가자 격증으로 국한하여 정리하였다. 
김 진 등 / ‘사이’에서 고민하는 학꾜상담자(전문상담꾜사와 전문상담사)의 개성화를 위한 자기성장 스토리에 대한 자문화기술지 - 모래놀이치료와 꿈분석 집단에서의 성찰을 중심으로-

표 1. 연구 참여자 인적사항

\begin{tabular}{|c|c|c|c|c|c|c|c|c|}
\hline 순번 & 참여자 & 설립구분 & 근무지 & 성별 & 연령 & 상담 경력 & 상담관련자격 & 학력 \\
\hline 1 & A교사 & 공립 & ○○초등학교 & 여 & 31 & 8년 2개월 & $\begin{array}{l}\text { 전문상담교사 } 1 \text { 급 } \\
\text { 청소년상담사 } 3 \text { 급 }\end{array}$ & 석사 재학 \\
\hline 2 & $\mathrm{~B}$ 교사 & 공립 & OOWee센터 & 여 & 38 & 3년 5개월 & $\begin{array}{c}\text { 전문상담교사 } 1 \text { 급 } \\
\text { 모래놀이상담사 } 2 \text { 급 }\end{array}$ & 석사 졸업 \\
\hline 3 & C교사 & 공립 & ○○초등학교 & 여 & 36 & 9년 1개월 & $\begin{array}{l}\text { 전문상담교사1급 } \\
\text { 청소년상담사2급 } \\
\text { 모래놀이상담사 } 1 \text { 급 }\end{array}$ & 석사 졸업 \\
\hline 4 & $\mathrm{D}$ 교사 & 공립 & $\bigcirc \bigcirc$ 초등학교 & 여 & 33 & 2년 5개월 & 전문상담교사2급 & 석사 졸업 \\
\hline 5 & E교사 & 공립 & ○○초등학교 & 여 & 59 & 9년 5개월 & $\begin{array}{l}\text { 청소년상담사 } 2 \text { 급 } \\
\text { 임상심리사2급 } \\
\text { 전문상담사 2급 }\end{array}$ & 석사 졸업 \\
\hline 6 & F교사 & 공립 & $\bigcirc \bigcirc$ 중학교 & 여 & 35 & 3년 8개월 & $\begin{array}{l}\text { 전문상담교사 } 1 \text { 급 } \\
\text { 청소년상담사 } 2 \text { 급 }\end{array}$ & 석사 졸업 \\
\hline 7 & $\mathrm{G}$ 교사 & 공립 & $\bigcirc \bigcirc$ 중학교 & 여 & 46 & 10년 & $\begin{array}{c}\text { 전문상담교사2급 } \\
\text { 청소년상담사2급 } \\
\text { 임상심리사2급 } \\
\text { 모래놀이상담사 } 1 \text { 급 }\end{array}$ & 석사 졸업 \\
\hline 8 & $\mathrm{H}$ 교사 & 공립 & ○○고등학교 & 여 & 51 & 9년 4개월 & $\begin{array}{c}\text { 청소년상담사2급 } \\
\text { 임상심리사2급 } \\
\text { 모래놀이상담사 } 1 \text { 급 }\end{array}$ & 박사 재학 \\
\hline 9 & I교사 & 공립 & ○○고등학교 & 여 & 34 & 5년 5개월 & $\begin{array}{l}\text { 전문상담교사2급 } \\
\text { 청소년상담사 } 2 \text { 급 }\end{array}$ & 석사 졸업 \\
\hline 10 & J교사 & 사립 & $\bigcirc \bigcirc$ 고등학교 & 여 & 55 & 5년 & $\begin{array}{c}\text { 전문상담교사1급 } \\
\text { 임상심리사2급 } \\
\text { 청소년상담사2급 } \\
\text { 모래놀이상담사 } 1 \text { 급 }\end{array}$ & 석사 졸업 \\
\hline 11 & $\mathrm{~K}$ 교사 & 공립 & $\bigcirc \bigcirc$ 고등학교 & 여 & 44 & 11년 5개월 & $\begin{array}{c}\text { 전문상담교사1급 } \\
\text { 청소년상담사2급 } \\
\text { 모래놀이상담사 } 1 \text { 급 }\end{array}$ & 박사 재학 \\
\hline
\end{tabular}

\section{3. 연구절차}

연구자/연구참여자들은 12 시간의 집단 꿈분석과 100 시간의 모래놀이치료 워크숍에 참여 하였으며 집단리더와 1 회의 개별 인터뷰를 실시하였다. 이 과정은 2019년 4월 6일부터 2020년 11월 29일까지 지속되었다. 연구자가 두 명 이상이기 때문에 주제 선정과 자료 수 
Journal of Symbols \& Sandplay Therapy, Vol.12 No.2.

집 및 기술, 자료 분석과 이를 위한 이론 선정, 범주의 분석 및 분류, 연구 결과에 대한 제 언에 이르기까지 모든 연구자가 공동으로 진행하였다. 이 모든 과정에서 공동연구자들 간 의 빈번한 토론과 동의하기, 보완하기, 이어글쓰기 등이 이루어졌다. 구체적인 서술방식으 로, 주관적 정서를 중심으로 기술하는 고백적-감성적 글쓰기(confessional-emotive writing)가 이 루어졌다(김영천, 2013, 박은영, 김명찬, 2018; Chang, Ngunjiri \& Hernandez, 2013). 모래놀이치 료와 꿈분석 작업이 종료된 후에도 SNS를 통해 떠오르는 아이디어와 소감 등을 지속적으로 나누었고 논문을 작성하는 모든 과정 또한 공유했다.

\section{4. 자료수집 및 연구의 엄정성}

연구주제와 관련하여 사용된 자료는 다음과 같다.

- 기억자료: 꿈과 꿈 연상, 모래놀이치료와 연상, 관련 삶의 사건과 경험

- 모래장면 사진자료

- 자기성찰자료: 사색, 회상, 의식, 통찰 등

- 관찰자료: 연구자/연구 참여자들의 관찰

- 집단 SNS 공유내용

- 개별 인터뷰자료, 기타

본 연구에 사용된 분석 자료는 총 1,530 개의 자료에서 추출되었다. 자료의 유형은 삼각검 증을 위한 기억자료, 사진자료, 자기성찰자료, 관찰자료, 집단 SNS 공유내용, 인터뷰자료 등 이다. 기억자료에는 연구자/연구 참여자들이 상담자에게 필수인 자기분석을 위해 참여한 2019년 4월 6일부터 2020년 11월 29일까지 참여한 12시간의 집단 꿈분석과 100시간의 모래 놀이치료 워크숍에서의 자기경험 그리고 꿈분석 작업에서의 꿈 내용과 모래상자 및 꿈 내 용에 대한 연상과 삶의 경험 및 사건이 포함된다. 모든 세션은 녹음되었으며 모래상자는 사진을 찍었다. 사진자료는 모래놀이치료 워크숍에서 각자가 만든 모래장면 사진이다. 각자 총 156 장의 사진을 갖고 있다. 자기성찰 자료에는 모래놀이치료와 꿈작업 시간 외에 기억 하거나 생각하게 된 각자의 경험과 삶에 대한 사색, 회상, 상상, 통찰 등에 대해 언급이 포 함되었다. 관찰 자료는 함께 모래놀이치료 워크솝과 꿈분석 작업에 참여한 연구자/연구 참 여자들의 관찰을 바탕으로 한다. 이 관찰에는 서로의 변화과정, 공동의 성찰에 대한 언급이 포함되었다. 이외에도 모래놀이치료와 꿈분석 작업을 마친 후에 개별적으로 이루어진 인터 뷰 내용이 포함되었다.

연구의 타당도를 확보하는데 기여했다고 판단되는 부분은 다음과 같다. 첫째, 각 참여자 의 언급을 전사한 내용과 결과분석의 전 내용을 연구 참여자들에게 제시하고 피드백을 받 
았다. 둘째, 전사한 내용과 관찰에 근거한 피드백은 각 연구 참여자의 자료에 대한 오류를 줄이는데 기여하였다. 셋째 결과분석을 지지하는 설명을 찾기 위해 연구논문과 기존에 개 발된 이론으로 지지하고자 하였다. 마지막으로 연구에 포함되지 않은 다른 전공 교수 1 인 에게 전문적인 의견을 구했다.

\section{4. 연구윤리}

자문화기술지는 연구자와 연구 참여자들의 '자기 노출이 불가피하나 인간을 대상으로 하 는 연구윤리 측면에서 연구 참여자의 보호' 문제가 발생할 수밖에 없다(김명찬, 2015). 이 에 대해 기존 연구윤리의 대안적 방안으로 자문화기술지 연구방법을 위한 관계적 윤리 (relational ethics)'를 제시하기도 하였다(김명찬, 2015; Ellis, 2007). 김명찬에 의하면, 관계적 윤 리란 연구 과정에서 연구자와 연구 참여자 간의 '친밀감', '상호신뢰와 존중' 등을 바탕으로 하여 진행되어야 하며 연구 과정이 부정적인 반응을 가져올 경우를 대비한 대안을 갖고 있 어야 한다. 연구 과정이 불러올 수 있는 부정적인 결과에 대해 인지하여 그것을 제거하는 것 그리고 연구 전체에 대한 동의가 아닌 구체적인 연구 과정에 대한 과정 동의(process contents)'가 그 대안이 될 수 있다는 김명찬 $(2015,2013)$ 의 논거를 따랐다. 또한, 연구 참여자 들의 사적 정보나 연구 참여자 주변인들의 정보가 노출되지 않도록 하는 조처를 하였다. 연구자/연구 참여자들 간의 지속적인 대화를 통해 연구자/연구 참여자에 관한 민감한 정보 나 연구자/연구 참여자들의 주변인에 관한 정보가 노출되지 않으면서도 연구의 취지를 살 리는 방안을 계속 논의하였다. 또한, 연구 참여자 간의 공유된 정보에 대해서도 비밀보장 의무 및 예외적 사항에 대한 합의적 동의를 이루었다.

\section{III. 연구결과: 직업과 삶의 정체성을 찾아가는 여정}

정체성은 여러 가지 요소로 구성된 개념이며 그 중 직업과 삶 자체에 대한 개인의 정체 성은 특정한 직업에 대한 사명과 개인적 욕구를 충족시키고 긍정적 삶을 지속하게 하는 중 요한 요인이다(Erikson, 1994). 동시에 직업과 개인의 삶은 조화를 이루어 전인적으로 통합되 기도 하지만 충돌을 일으키고 개인으로 하여금 갈등에 빠지게 하면서 두 부분 모두에 대한 열의를 상실하게도 한다. 그러나 두 가지 요소 간의 조화와 통합은 점진적인 것이며 환경 적 요인과 개인적 요인이 상호작용한다. 전문상담교사 그리고 전문상담사로서 우리들의 여 정 또한 이러한 전철을 밟고 있다고 판단된다. 이 둘 간의 요소가 한 개인과 집단 안에서 성장과 개성화를 담고 있다. 
Journal of Symbols \& Sandplay Therapy, Vol.12 No.2.

\section{1. '청운'의 꿈}

우리는 교과 교사 또는 상담사였거나 처음부터 상담교사로 임용된 사람들로서, 전문상담 교사 또는 전문상담사가 되어 힘들어하는 아이들을 돕고자 하는 일념을 갖고 어렵게 관문 을 통과했다. 그야말로 '청운의 꿈'을 갖고 우리의 '전문직'을 시작했다. 무엇인가 내가 한다 면 아이들이 좋아지지 않을까 하는 푸른 꿈을 갖고 있었던 것이다.

\section{[2019.9.21. 모래놀이치료 워크숍]}

상담 쪽에 관심이 많았어요. 고등학교 때는 상담동아리 활동도 했었고, 대학 학 과 선택도 그런 꿈을 가지고..., 사회에 나와서 내가 하고 싶은 걸 이룬 게 감사하 게 느껴지기도 하고요.(연구참여자 A)

저의 (대학)졸업식 장면을 꾼 꿈이에요. 제가 졸업장을 받을 때 아빠가 저의 짐 을 들고 저 뒷자리에서 축하해주고 있어요. 제가 상담교사가 됬을 때 무척 좋아 하시고 기빼해 주셨어요.... 힘든 친구들을 돕고 싶은 마음에서 상담을 시작했어요. 나름의 전문성을 가지고 학교에서 상담을 한다 생각.....(연구참여자 $C$ )

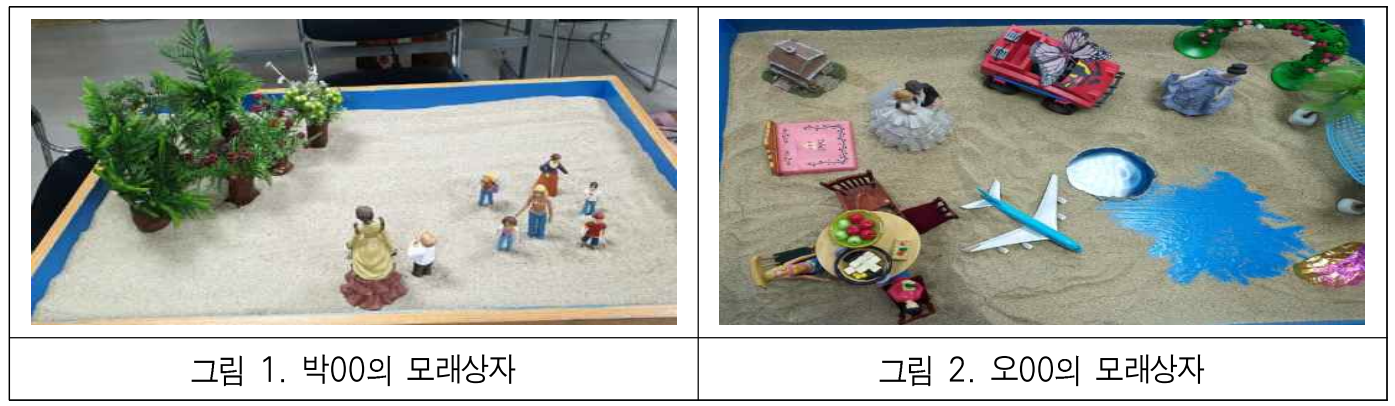

2. 좌충우돌, 좌절: 자책과 원망

'청운'의 꿈을 갖고 우리의 전문직을 시작한 우리는 현실에 부딪히는 경험을 피할 수 없 었다. 이상과 현실은 다르다는 것을 알고 있다고 생각했으나 우리가 맞닥뜨린 현실은 달랐 다. 나는 혼자였고 학교 안에서 내 일과 내 고민을 공유할 수 있는 동료가 없었다. 일대일 로 혼자 하는 상담, 비밀보장을 해야 하는 상담의 성격을 일반 동료교사들과 관리자에게 알리기는 더 힘들었다. 그것은 소외감을 느끼게 조차했다. 설명할 수 없는 소외감이었고 때 로는 개인의 이슈와 연결되면서 열등감과 자괴감 그리고 능력이 부족해서 소임을 완수하지 
못한다는 자책감마저 들게 했다. 교실에서 적응하지 못하는 아이들뿐 아니라 파괴된 가정 을 둔 아이들, 심각한 트라우마를 입은 아이들, 심지어 자살 충동을 가진 아이들을 대하면 서 한편으로 두려운 마음마저 들었다. 그야말로 좌충우돌, 좌절, 자책과 원망감이 우리의 삶을 감싸고 들 때가 있었다. 우리는 개인의 이슈와 시스템의 문제를 구분하지 못한 채 시 스템의 문제를 말하면서도 깊은 내면에서는 자신의 무능감, 열등함을 비난하고 있었다. 우 리는 잘해야 하고 인정받아야 하고, 남보다 나아야 하는 교육을 받고 살아왔다. 그러나 불 행한 것은 그러면서 동시에 무엇이 해결되어야 하는지조차 알지 못하면서 아이들에게 실질 적인 도움을 주지 못한다는 죄책감에도 시달렸다는 것이다. 이 죄책감은 가족에게까지 연 결되었다. 더욱 완벽하게, 잘한다는 인정을 받고 싶어 하는 개인적 이슈는 가족에게까지 확 대되어 잘하는 배우자, 잘하는 부모가 되려고 하게 만들었으며 결국 가족에게조차 잘하지 못한다는 죄책감에 지치고 고단한 삶을 만들어버렸다. 그러면서 우리는 '누구를 위한 삶인 가?’라는 의문조차 갖지 못했다.

\section{[2019.10.9 모래놀이치료 워크숍과 2020.7.-8. 꿈분석 작업]}

저는 어떻게 해야 할지 물어볼 때도 없고. 다른 학교 선생님들한테 물어 물어 서 행사를 어떻게 하긴 했는데 교장선생님이나 다른 선생님들은 제가 어떻게 했 는지 알아주지도 않고, 관심도 없는 것 같고, 당연하게 여기는 거 같아요. 잘못된 것만 애기하니까. 제가 무능한 것 같기도 하고 $\cdots$. 다른 선생님은 어떻게 하나 모 르겠어요.(연구참여자 $B$ )

학교에서 동 학년에 보건선생님, 영양선생님, 특수교사 선생님 두 분 이렁게 비 담임교사, 비교과 선생님들하고 함께 있어요. 그래서 이제 애기하다 보면 아무도 우리가 하는 게 어떤 건지 모른다, 그래서 서럽다, 이런 애기를 공통적으로 함께 해요. 그래서 제가 메인이 아니라는 것에 대한 느낌은 뭔가 개척하는 느낌도 있 기는 한데... 외로운 느낌이 좀 많은 것 같아요.(연구참여자 $K$ )

학교 일에 집중하다 보면 집에 애들에 대한 미안함, 걱정이. 그러다가 몸이 너 무 힘드니까.(연구참여자 $E$ )

공부하러 여기저기 다 쫓아다녔죠. 남들은 잘하는 거 같아수... 자격증을 따면 실력이 생길 것 같았어요. (연구참여자 $F$ )

왜 그렇게 공부해야 하는 것들이 많은 건지... 도와주지 않는 남편이 미워요.(연 구참여자 $D$ ) 


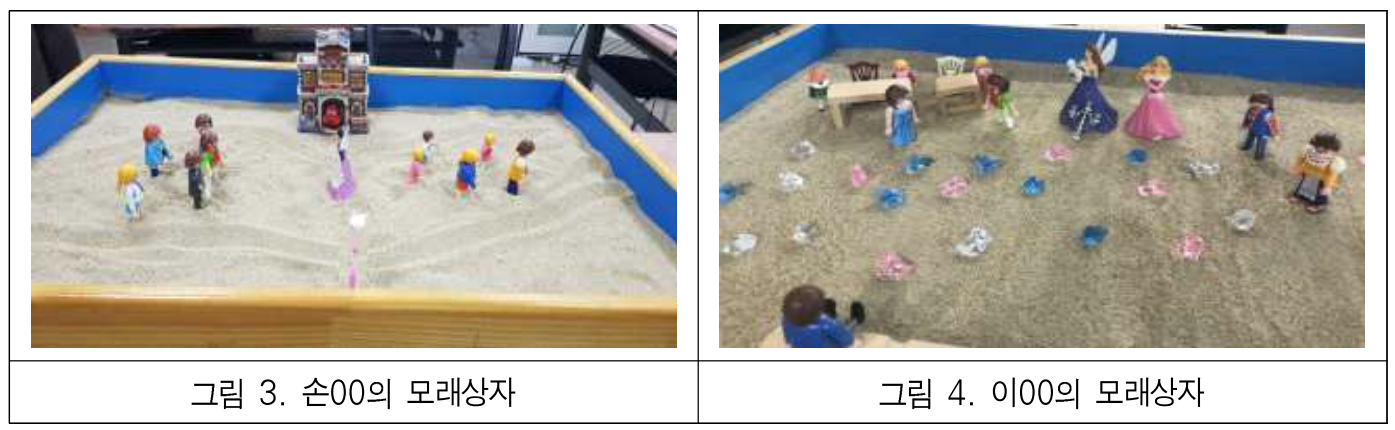

3. 돌파구의 모색: 정체성 찾기

그래서 우리는 우리의 부족함, 열등감, 무능감을 채워주고, 무엇인가가 잘못되었다는 혼 란감을 해결해줄 방법을 찾아 나섰다. 이것저것을 경험하고 배우면서 모래놀이치료, 꿈분석 작업에까지 이르게 되었고 우리 자신의 문제와 우리가 처한 상황의 문제들이 어떻게 우리 안에서 작용하고 있는지 알고자 했다. 우리 문화와 사회에서 태어나고 살아오면서 성공, 성 취, 인정에 대해 우리가 얼마나 한쪽으로 치우친 가치관을 가지고 스스로를 괴롭히며 살아 왔는지 깨달아갔다.

[2019.4.6.-2020.6.21. 모래놀이치료 워크숍 그리고 2020.7.-9. 꿈분석 작업과 2020.12.27.12.28. 인터뷰]

1) 모래놀이, 꿈: 내면과의 조우

무엇 때문에 그렇게 힘들어하면서 살았는지에 관해 자신의 내면의 소리를 듣는 과정이 이루어졌다. 성공, 성취, 인정만이 잘 사는 것이라 문화가 우리를 몰아쳤고 이제는 내면화 된 내면의 소리가 우리를 몰아부쳤다는 것을 알게 되었다.

이 작업을 통해 나를 알게 되었다고 할까요?(연구참여자 $A$ )

시간이 흐르면 자연스레 해결되는 부분이 있어요. 여유라고 해야 하나요? 저는 전문성은 여유에서 온다고 생각하는 것도 있거든요. 삶에 대한 여유, 나 자신에 대한 여유, 타인에 대한 여유, 내 역량에 대한 여유... 그런 생각이 들면서 올 한 해도 열심히 살고, 제가 배운 만큼 아이들에게 전해주고 싶은 느낌이 들었어요. (연구참여자 B) 
김 진 등 / '사이'에서 고민하는 학꾜상담자(전문상담꾜사와 전문상담사)의 개성화를 위한 자기성장 스토리에 대한 자문화기술지 - 모래놀이치료와 꿈분석 집단에서의 성찰을 중심으로-

저한테 그렇게 잘하려고 하는 마음이 있는 줄 몰랐어요. 상사나 동료가 피드백 을 좋게 주 지 않는 것 같으면 그 사람과 웬지 멀어진 것 같고 나를 인정해주지 않는 것 같고. 학교 생활 하는 게 힘들었죠.(연구참여자 $D$ )

꿈분석은 놀라운 경험이에요. 모래상자를 만들 때만 해도 엄마에 관한 생각은 전혀 하지 않았는데 결국 또 저의 문제와 맞당아 있었어요. 탈출하려는 (교수님 이)저를 가리키며 놀라는 엄마를 나타내는 듯한 피겨를 이야기하시며 제 손은 이 미 알고 가져다 놓았다는 말씀이 인상 깊습니다. 좋은 경험 하게 해주셔서 감사 해요.(연구참여자 $C$ )

자신을 좀 더 존중하고 아끼고 챙겨야 하겠다는 생각. 알고 있었던 것이지만 소홀히 했던 것들을 돌아보게 하는.(연구참여자 $G$ )

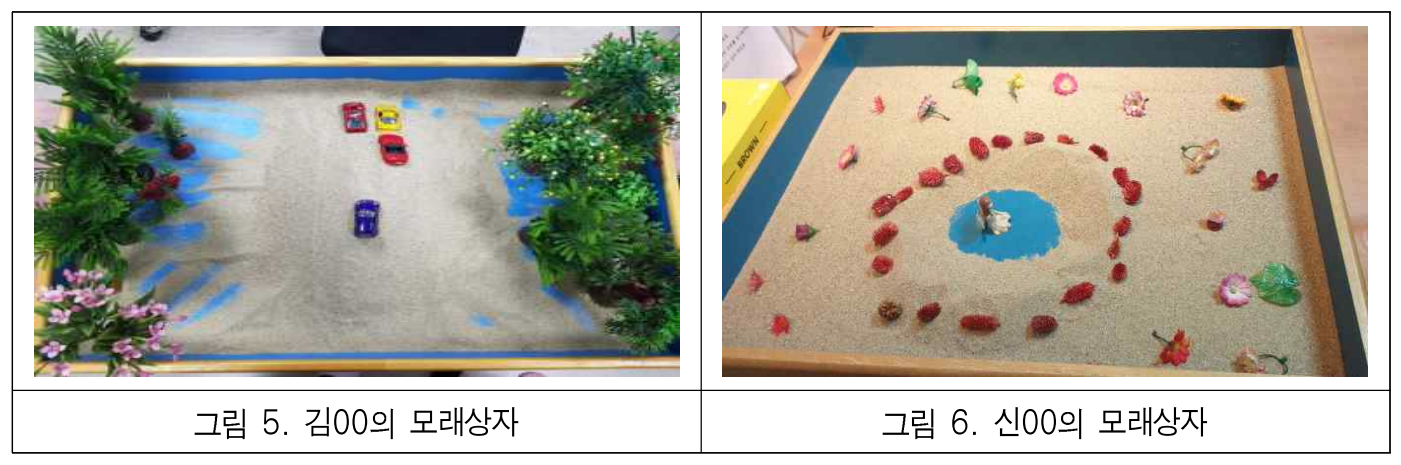

2) 아이들에 대한 안타까움과 씨름하기

아이들과 상담에서도 우리는 씨름해야 했다. 상담을 잘 해내야한다는 강박관념과 씨름했 고 아이들이 처한 상황 때문에 아이들이 무고하게 안고 있는 고통과 씨름했다.

내담 학생들의 문제 스펙트럼이 넓어서 깨진 독에 물 붓기인 아이도 있어서 외 부기관에 연계해도 비용 때문에 오래 지속하지 못하고... 상담자로서 다 커버하지 못하는 한계... 빨리 캐치하고 도와줄 수 있는 능력이 있으면 하는 자질에 대한 자괴심... 일반교사와 공유해도 보는 시각 자체가 달라 보호나 변호를 해줘야 하 는 입장에 있게 되더라고요. 부모 역할을 해야 할 때도 있고. 너무 많이 안타까워 하기도 하고. 내가 어디까지 해야 하나 싶은 역할 혼란도 있고요.(연구참여자 $H$ )

모래상자로 한 회기를 온전히 상담을 했는데 너무 뿌듯하더라고요... 언어상담 
Journal of Symbols \& Sandplay Therapy, Vol.12 No.2.

수련을 먼저 받아서 몸에 배어 있어서 모래놀이 하다가도 맥이 귾기면 언어상담 을 하려고 했는데 12월 초에 할 때는 온전히 모래 안에서만 했더니 너무 좋더라 구요. 아이가 상징으로 자신을 표현하는 게 느껴졌어요. 짠하기도 하고 $\cdots$. 말을 많이 한 것도 아니었지만, 상징으로 자신을 표현하는 아이가 느껴졌어요.(연구참 여자 $J$ )

2019년에 전에 그 학교에서 있었던 일인데, 상담을 하다가, 학부모를 만나야 할 일이 생겼어요. 근데 이 학부모가 너무 문제가 심각한 거예요. 그래서 뮌가 아이 를 돕기 위해서는 이 학부모에게 뭔가를 잘 못 됐다. 이야기를 해야 하는구나. 말 하자면 직면을 시켜야 하는구나. 네, 근데 그게(부모상담) 너무 힘들었어요.(연구 참여자 $K$ )

저 자신의 어릴 때 모습을 발견하면서 내담자들에게 뭔가를 자꾸 너무 해주고 싶어 하고 도와주고 싶어 하는지 알게 되었어요. 그 부분을 알게 되었을 때 많이 울었죠. 그 경험을 하게 되면서 평탄하게 살아왔다고 생각되는 나한테도 이런 게 있는데 겉으로도 힘들어 보이는 내담자들은 얼마나 힘들까 라는 생각이 들었죠. 그런 경험을 하게 될 거라 생각을 못 했기 때문에 당황스러웠어요. 그때 내가 지 금 이런 걸 알았더라면 $\cdots$. 후회되고 미안하고...(연구참여자 I)

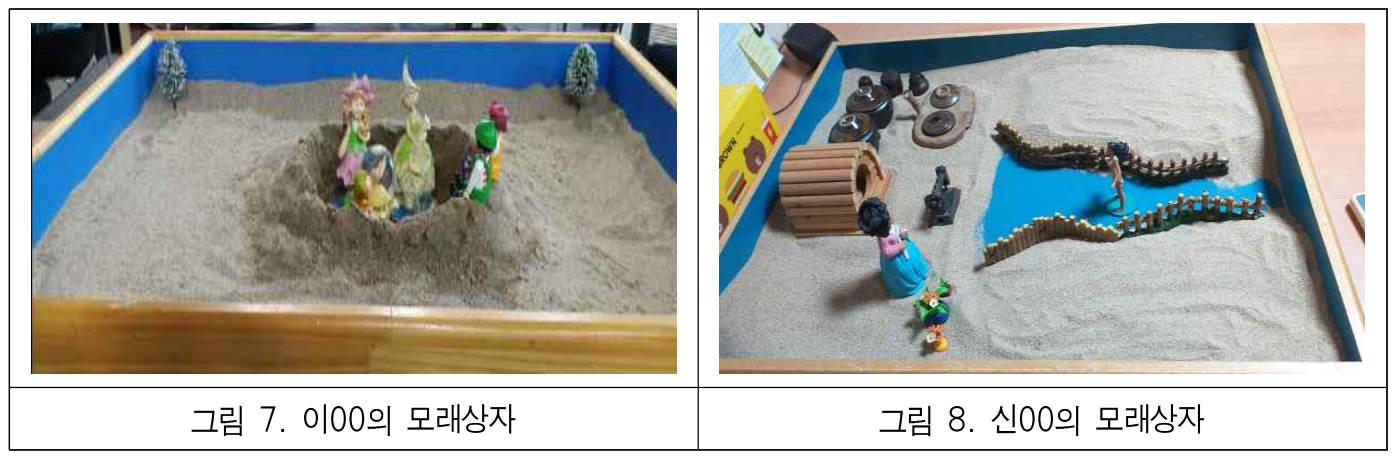

\section{4. 불완전함을 받아들임 그러나 아직 진행 중임}

지금까지의 고민, 그리고 이러 저리 뛰어다니며 해 온 수많은 공부와 노력에도 불구하고 모든 환경, 집단, 제도, 개인은 불완전하다는 것을 받아들이게 되었다. 또한 개인의 삶에 존 재하는 불완전함도 어느 정도 받아들이게 되었다. 그러나 아이들을 위해 그리고 우리 자신 을 위해 제도, 사회를 변화시키겠다는 직업적 일념은 버리지 않았다. 
김 진 등 / '사이'에서 고민하는 학꾜상담자(전문상담꾜사와 전문상담사)의 개성화를 위한 자기성장 스토리에 대한 자문화기술지 - 모래놀이치료와 꿈분석 집단에서의 성찰을 중심으로-

[2020.7.-9. 꿈분석 작업과 슈퍼비전 그리고 2020.12.27.-12.28. 인터뷰]

저의 대극적인 모습에 대해 계속 생각하게 되었어요. 두 영역에서의 균형이 중 요하다는 생각... 과거의 패턴 즉 도덕적이고 이성적 자신을 통제하려고 하고... 그 렇지 못할 때는 괜창다고 생각하고 이것도 나의 모습이라고 생각하면 여유가 생 겼습니다... 내담 학생들도 마찬가지인 거 같아요. 반대 부분을 보게 하고. 자해나 자살사례에서 살고 싶은 의지가 크다는 것을 알았고 살고 싶은 의지가 강해서 자 살하고 싶어 하는 것이라는 설명을 해주고... 아동에게 나타나지 않은 모습을 보 려고 하는 관점도 생겼구요. 균형을 맞추려고 하는 태도가 생겼다고 할까요.(연구 참여자 $F$ )

내담 아동들과 모래상담을 하면서 책에 나오는 칼프나 노이먼이 이야기하는 성 장 과정이 드러나는 것을 보고 신비하고 그것을 경험했던 것 같아요... 그래서 아 동이 하는 것을 따라가면 자연스럽게 발달하고 변화한다는 믿음을 더 갖게 되었 어요.(연구참여자 $G$ )

학교상담이 가진 특수성 때문에 외부 슈퍼비전 받을 때 정체성에 문제가 생기 는데 이 부분에 대해 슈퍼바이저가 이해해주어서 편안하고 감사한 마음이에요. 학교에서 배운 것과 현실이 다르니까 초보교사들은 거기서 혼란스러워하고... 그 런 것들과 관련된 학교상담법이 생겨야 해요. (연구참여자 I)

일방향을 달리는 삶을 살고 있다는 것을 깨달았어요. 남편의 처지도 생각해보 게 되고... 건강해진 삶이라고 할까요. 과거에는 부족한 부분을 채워야 한다는 생 각, 더 공부해야 하고 더 배워야 한다는 강박적인 데가... 그것을 알아차리고 나 니 그것 때문에 놓쳤던 가정, 남편, 일상의 소중함 같은 것을 더 느껴요. 남편에 게 애기 더 보라고 하고 내 자신의 외부활동에 대해 더 서포트 해달라고 요구했 었죠... 남편도 남편의 어려움이 있을 텐데...(연구참여자 J)

이번 모래놀이치료 교육에서 역전이적인 부분을 통해서 나 자신에 대한 이해가 되었어요. 상담이 여유로워졌고요... 청소년상담을 하고 있는데 학생들에 대해 어 떤 마인드를 갖고 있는지 알게 되었고 우리 친구들은 잘할 수 있고 잘 되길 바라 는 긍정적 마인드를 갖고 있다고 생각하고 있다 보니 내가 너무 많이 애쓰고 내 가 뭔가를 하려고 했어요... 그러다 보니 공감, 수용, 여유가 오히려 부족했죠. 내 담자에 대한 신뢰가 생겼다고 할까.요.(연구참여자 $A$ )

다방면으로 공부하려고 했던 이유를 생각해보니 (학교에서)학습, 정신건강, 부 
Journal of Symbols \& Sandplay Therapy, Vol.12 No.2.

적응, 사회복지적 측면까지 다 다루어야 하다 보니 그렇게 되었다는 생각도 들어 요. 그런 생각은 못 하고 개인적으로 부족하다고만 생각하고 고달프게 여기저기 쫓아다니며 공부하느라 힘들었어요. 부족하다는 관점에서만 생각했으니까요...연 구참여자 $G$ )

모래놀이치료는 직접 체험해보니 초등학생들에게도 사용하게 되고 학폭 가해학 생과 부모에게 교육방법으로 사용해봣더니 서로 서로가 이해를 하게 되더라구요. 해석해주지도 않아도 분위기, 느낌을 보고 부모가 아이를 이해하고 아이도 부모 를 이해하는 과정이 생기더라고요. 자격증을 따고 나서 용기가 생겨 필요한 교사 에게 해주었더니 매우 좋아했어요. 상담초반에 말을 잘 안 하려고 하는 아이들에 게 접근하기도 좋았구요...(연구참여자 $C$ )

모래놀이치료 수련 과정에 참여하기 전에는 내담자에게 공감이라기보다는 내담 자에게 어떤 일이 있었는지 궁금해하는 상담자였어요. 모래놀이치료 수련을 시작 한 후에는 내담자에게 일어난 일보다 어떤 마음이었는지 집중하려고 하는 태도 변화가 생기더라구요. 모래놀이치료 공부 전에는 상담교사들끼리 어떤 이론을 갖 고 있냐는 애기를 하면서 여러 교육을 찾아다니며 나만의 이론을 가지려고 했던 때도 있었어요... 그러나 이제 내담자에게 더 귀를 기울이는 태도를 갖게 되었어 요. (연구참여자 $D$ )

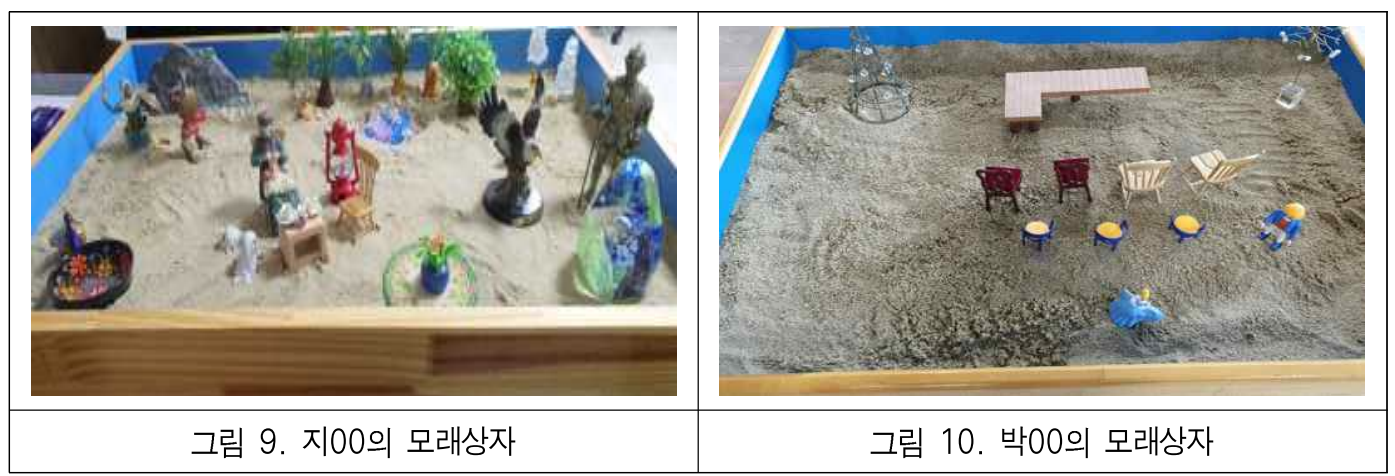

\section{IV. 결론 및 제언}

본 논문은 모래놀이치료와 꿈 상징분석 작업을 통해서 우리 전문상담교사와 전문상담사 11 명은 모래놀이치료를 학교상담에 적용한 경험과 상담 장면의 변화와 함께 자기성장과 
개성화의 길을 어떻게 걷고 있는지에 관한 자문화기술지이다. 학교상담자로서의 어려움, 그 안에서의 좌절과 노력, 돌파구를 찾아가는 과정에서 발견한 몇 가지의 시사점은 다음과 같다.

첫째, 학교상담이 가지는 특수성으로 인하여 상담자로서 균형감을 가지고 학교 안에서 존재하는 것의 어려움을 나누었다. 교사와 상담자 사이에서 업무에 대한 혼란과 역할 갈등 을 겪고 있었으며, 이런 갈등과 좌절 원인을 개인의 역량의 부족이나 환경에 대한 원망으 로 귀인 하였다. 예를 들면, 성공, 성취해야 한다는 생각에 자신의 열등함, 무능함을 탓하거 나 역량을 충분히 발휘할 수 있도록 돕지 않는 배우자나 부모를 원망하거나 자기들끼리 뭉 쳐 인정해주지 않는 것 같은 일반교사와 행정리더를 원망하였다. 그러면서 한 편으로 열등 감, 부족함을 채우기 위해 여기저기 좋다는 곳은 공부하러 끊임없이 뛰어다니며 노력했던 모습들을 상기하였다. 그리고 학교상담 환경의 여러 장벽에 노출된 학교상담자가 얼마나 쉽게 소진될 수밖에 없는 위치 또는 환경에 있는지 절감하였다. 모래놀이치료 워크숍과 꿈 분석을 통해 공감대를 이루면서 이 모든 것들이 각자의 경험이면서 동시에 우리의 경험이 었음을 알게 되었다. 모래장면 만들기와 꿈분석 과정을 통해 개인의 문제가 수면으로 떠올 라졌고, 개인의 문제를 함께 나누고 위로하는 과정을 통하여 불완전함을 수용하는 경험이 되었다, 우리의 경험과 삶을 돌아보고 더 나아가 그것을 타인, 사회/문화적 맥락에서 돌아 볼 수 있었다. 그 과정에서 더 깊은 통찰과 넓은 조망을 갖게 되었으며, 전문상담교사 및 전문상담자로서의 정체성을 찾게 되었으며 이것이 치유를 가져왔다는 것을 깨달았다.

또한 이러한 나눔을 통해 전문상담교사 및 전문상담자들은 현재 좌절과 소진을 견뎌야 하는 상황에 있음을 인식하고, 어려움과 대면할 담대함이 필요함을 비로소 알게 되었다. 2005년 9월, 학교상담 업무를 전담으로 하는 전문상담교사의 배치가 시작된 이래로 17년이 지났다. 이제는 학교상담자 스스로 고유한 정체성을 확립하여야 하고, 학교 상담의 주체가 되어야 할 것이다.

둘째, 모래놀이치료에 대한 학문적인 이해를 통해서, 상담자로의 태도와 마음가짐에 변화 를 가져왔으며, 이는 상담 역량에도 크게 영향을 미침을 경험하였다. 내담자가 의식하지 못 하거나 언어로 표현하지 않았던 내면의 무의식적인 부분들은 모래상자 안에 투사되고 상징 으로 드러났으며, 이를 통해 파생되는 감정, 상상, 연상 등을 민감하게 알아차림으로써 함 께 나누면서 서로의 상호주관성을 이해하는 경험을 하였다. 모래놀이치료 작업의 방향은 무의식을 의식에 통합시켜 의식의 범위를 확장하고 자아를 새롭게 하여 인격 발달의 전체 성을 이루고자 함에 있고, 무의식을 의식화하기 위해 상징을 활용하고 있으며 모래, 모래상 자, 피겨 등이 상징으로써 그 역할을 한다. Winnicott(1971, 장미경, 2018 재인용)의 대상관계 이론에서 테디베어나 포근한 담요가 중간대상으로서 관계 맺으며 서서히 어머니에게서 분 리되는 것을 돕는 것과 같이, 모래상자는 치유와 성장을 위한 중간 영역의 역할을 해주었 
Journal of Symbols \& Sandplay Therapy, Vol.12 No.2.

다. 다중관계의 위험에 빠질 수 있는 학교 상담 장면에서 모래상자를 통해서 전이와 역전 이를 보다 더 안전하게 다룰 수 있었다. 미처 인식하지 못하거나, 언어로 표현하지 못하는 아동- 청소년에게 좋은 상담의 방법으로 쓰여질 수 있음을 경험하였다. 또 모래상자의 변 화과정을 보면서 아동·청소년의 변화를 직접 눈으로 보고 온몸으로 느끼게 되었다.

마지막으로 이 논문은 전문상담교사와 전문상담사 11 명이 학교 상담의 실제를 경험하고 운영하며 체험한 진솔한 이야기를 반영하였다는 측면에서의 현장 연구로서의 가치와 중요 한 의미가 있다.

학교상담에는 전문상담교사와 전문상담사만의 노력으로 개선하기 어려운 여러 가지 외적 문제들이 존재한다. 우리가 얻은 깨달음과 우리의 어린 내담자들을 위해 품은 희망이 미래 의 현실이 되기 위한 밑거름이 되도록 몇 가지 제언을 하고자 한다.

첫째, 우리의 자문화기술지 연구를 통해 학교 상담의 특수성으로 인하여 너무나 많은 '사 이'에서 학교상담자들이 역할 갈등과 혼란을 겪고 있다는 것을 인식하였다. 전문적인 상담 을 흔들고 시험하는 학교 환경 속에서 학교상담자들은 스스로 고군분투하고 내담자를 보호 하며 학교 상담 영역을 지켜왔다. 많은 학교상담자들 개개인의 노력으로 점차 인식의 개선 이 이루어지고 있으나, 보다 거시적인 관점에서의 인식의 개선 노력이 함께 수반되어야 한 다. 학교 상담 공간이 비밀보장이 이루어지는 어린 내담자의 내면과 삶의 변화가 방해 없 이 귀하게 이루어져야 하는 '테메노스'가 되어야 하는 이유와 중요성에 대하여 학교 관리자 와 일반교사에게 인식 개선 교육이 필요할 것이다.

둘째, 모래놀이치료 작업과 꿈분석을 통해서 연구자 11 명은 모두 '치우침'과 '균형'에 대 해서 자각하고 성찰해봄으로써 성숙해 가는 우리를 발견하였다. 과거의 학생을 지도하고 교육하던 초창기 방식이 여전히 학교상담 현장에 남아있다. 일방향적인 조언이나 충고가 아닌 새로운 교육의 새 패러다임에 걸맞은 상담으로 나아가기 위해서 내담자 중심의 상담 적 접근이 필요할 것이다. 이와 더불어, 학교상담이 언어에 치우친 상담적 접근의 편향성에 서 보다 전문성을 가진 상담으로 나아가기 위해 모래놀이치료나 놀이치료 등과 같은 아동 중심 상담 등의 다양한 이론과 심리치료 기법들이 유연하게 학교상담 장면에 소개되고 적 용되기를 바란다.

셋째, 학교 상담자를 위한 수련 규정이 학교상담법 또는 상담조례와 같은 법과 제도 안 에서 다루어질 필요가 있다. 일선 학교 장면에서의 상담 장학에 있어서 수업 공개의 개념 과 혼선이 있으며, 교원 평가나 전문적학습공동체 운영 등에 있어서도 전문상담 영역에 걸 맞게 명확한 지침이 필요하다. 더 나아가 전문상담교사와 전문상담사의 전문성 함양과 전 문 상담의 질 관리를 위하여 교육분석 등을 통한 지속적인 자기 점검과 연찬 및 수퍼비전 (장학)에 대한 가이드라인이 필요하다. 이 역시 전문상담에 대한 이해를 바탕으로 전문상담 의 고유한 직무와 독립성이 보장되는 환경이 구축되어야 함을 의미한다. 
학교라는 특수한 상담 세팅과 상담이라는 전문성에 대한 이해 그리고 거기에 맞는 적절 한 훈련과 정체성의 보장은 학교상담자들의 소진을 막고 명확한 전문적 정체성을 형성하게 하며 학교상담자 개인의 삶과 일의 균형을 이루게 함으로써 더 집중력 있고 전문적인 상담 서비스를 미래의 주역들에게 제공하게 하는 초석이 될 것이다. 이러한 제언들은 우리가 연 구 과정에서 깨닫고 느낀 바를 토대로 추가적인 연구 및 정책 변화의 필요성을 제안하는 것이기도 하다. 학교 안의 전문상담이 공고화되고 과거의 낡은 인식과 틀에서 벗어나 궁극 적으로는 우리 아이들의 꿈과 잠재력이 발견되고 성장하는 토대가 되기를 간절히 희망하여 본다.

\section{참고문헌}

교육과학기술부 (2021). 전국 전문상담교사 배치 현황. 2021 국정감사 제공자료.

교육과학기술부 (2009). 전문상담교사 운영 및 활동 매뉴얼.

김근화 (2013). 학업소진과 부모성취압력의 관계에서 학업 통제감의 역할에 대한 종단연구:

잠재성장모형을 활용하여. 고려대학교 대학원 교육학과 석사학위논문.

김영천 (2013). 질적 글쓰기2-Methods. 피어슨 아카데미 프레스.

김명찬 (2015). "상처 입은 아버지와 아들"의 회복에 대한 자문화기술지. 한국교육인류학회.

교육인류학연구, 18(4), 85-120.

김인규 (2012). 학교상담 발전방안 연구. 전라북도교육청.

김인규, 조남정 (2011). DACUM법을 활용한 전문상담교사 직무분석 연구. 한국교원연구,

27(2), 97-115.

김정숙, 유금란 (2010). 전문상담교사의 역할갈등과 소진의 관계에서 전문직 정체성의 조절

효과. 한국심리학회지: 상담 및 심리치료, 22(1), 53-69.

김지연, 김동일 (2015). 전문상담교사의 직업적응 과정연구. 상담학연구, 16(1), 73-93.

김지정, 이영순 (2014). 전문상담교사의 적응과정. 한국심리학회지: 상담과 심리치료, 26(2),

223-246.

박근영, 임은미 (2014). 전문상담교사의 소진경험에 대한 개념도 연구. 중등교육연구, 62(1),

171-198.

박은영, 김명찬 (2018). 관계적 표상으로서 기억의 형성과 변환과정에 관한 협력적 자문화기

술지, 질적탐구, 4(2), 97-129.

박순용, 장희원, 조민아 (2010). 자문화기술지 방법론적 특징을 통해 본 교육인류학적 가치

의 탐색. 교육인류학연구, 13(2), 55-79. 
Journal of Symbols \& Sandplay Therapy, Vol.12 No.2.

송미라, 한기백 (2015). 과학고생이 지각한 부모양육태도와 주관적 안녕감의 관계: 학업적 자기효능감과 또래관계의 매개효과. 청소년학연구, 22(4), 93-111.

이명랑 (2018). 일-가정 갈등, 가정-일 갈등이 전문상담교사의 소진에 미치는 영향: 인지유연

성과 스트레스 대처방식 중심으로. 고려대학교 교육대학원 석사학위논문.

이자영, 남숙경, 박희락, 김동현, 이미경, 이상민 (2008). 진로의사결정 유형과 진로성숙도 간

의 관계에 대한 진로결정 자기효능감의 역할. 한국교육학연구, 14(1), 205-223.

이지원, 오인수 (2016).전문상담교사의 전문성 발달 경험에 관한 현상학적 연구. 상담학연구,

17(4), 351-372.

이상민, 안성희 (2003) 학교상담자는 무엇을 해야 하는가?. 상담학연구, 4(2), 281-293.

이현아, 이기학 (2009). 전문상담교사의 직무스트레스 요인과 직무만족도, 심리적 소진의 관

계. 한국심리학회지: 학교, 6(1), 83-102.

이현진, 김명찬 (2017). 복합외상 경험자의 자녀양육 경험에 대한 자문화기술지. 질적탐구,

3(2), 329-353.

장미경 (2017). 분석심리학적 모래놀이치료. 학지사.

장미경 (2018). 놀이치료. 창지사.

정환경 (2015). 전문상담교사의 역량 척도 개발 및 타당화. 경성대학교 대학원 박사학위

논문.

진혜은 (2014). 전문상담교사의 감정노동에 관한 질적연구. 우석대학교 석사학위 논문.

채현순, 장유진 (2016). 전문상담교사의 전문직 정체성 형성 과정에 관한 질적 연구. 전문상

담교사의 전문직 정체성 형성 과정에 관한 질적 연구. 한국교원교육연구, 33(4), 167-192.

최두호 (2012). 학교 성취압력의 학업성취에 대한 영향: 사회경제적 배경에 따른 차별적 효

과를 중심으로. 고려대학교 대학원 교육학과 석사학위논문.

최재진 (2010). 전문직적 특성의 교원 보수체계 반영에 대한 초중등 교원의 인식 연구. 한국

교원대학교 대학원. 박사학위논문.

한국교육개발원 (2011). 상담사 자격제도 개선 방안 연구: 학교상담을 중심으로. CR2011-36.

한아름, 오인수 (2014). 학교상담자의 직무스트레스와 심리적 소진의 관계에서 정서지능의

조절효과. 교원교육, 30(2), 227-251.

Burnham, J. J., \& Jackson, C. M. (2000). School counselor roles: Discrepancies between practice and

existing models. Professional School Counseling, 4(1), 41-49.

Chang, H. (2008). Autoethnography as method. Walnut Creek, CA: Left Coast Press, Inc.

Chang, H., Ngunjiri, F. W., \& Hernandez, K. C. (2013). Collaborative autoethnography. Walnut Creek, CA: Left Coast Press, Inc.

Ellis, C. (207). Telling secrets, revealing lives: Relational ethics in research with intimate others. 
Qualitative Inquiry, 13(1), 3-29.

Erikson, E. (1994). Identity and the life cycle. New York: W.W.Norton.

Jung, C. G. (1984/2001). 정신요법의 기본문제. 한국융연구원 융 저작 번역위원회.

Marcia, J, E. (1976). Identity six years after: A follow-up study. Journal of Youth and Adolescence, 5, $145-160$.

Reed-Danahy, D. (1997). Auto/ethnography: Rewriting the Self and the Social. Oxford and New York: Routlege.

Schore, A. N. (2014). 애착, 신경과학과 모래놀이치료. 한국임상모래놀이치료학회 2014 국제학 술대회 자료집.

Secord, P. F., \& Backman, C. W. (1964). Social psychology. New York: McGraw-Hill.

Skovholt, T. M. (2001). The resilient practitioner: Burnout prevention and self-care strategies for counselors, therapists, teachers, and health professionals. Boston, MA: Allyn \& Bacon. 